\title{
Recent research and development of ground column technologies
}

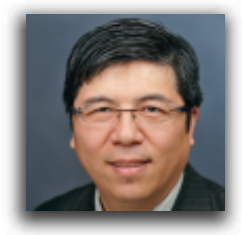

Jie Han PhD, PE

Department of Civil, Environmental, and Architectural Engineering, University of Kansas, Lawrence, Kansas, USA

In recent years, ground columns, such as vibro-concrete columns and geosynthetic-reinforced stone columns, have been increasingly used to support superstructures and embankments when they are constructed on soft foundations. Several new column technologies have emerged, including different shapes of concrete columns and composite columns. The column technologies have also been combined with other technologies to create more effective and/or economic solutions. However, the composite columns and the combined technologies have presented complicated geotechnical problems in design and construction. This paper summarises different types of column technologies and their functions, installation and applications, addresses design issues, and reviews recent research and development related to the column technologies to improve soft foundations, including failure modes, load transfer mechanisms, bearing capacity, settlement, consolidation and stability. Recent research has indicated that lateral deformation and yielding of columns should be considered in a unit cell model for the analyses of load transfer, deformation and consolidation. Several theoretical solutions have been proposed for the rate of consolidation of column-reinforced soft foundations. Different failure modes should be evaluated for the stability of column-supported embankments. Limit equilibrium methods based on shear failure overestimate the factors of safety of embankments on rigid or semi-rigid columns in soft soil.

\section{Notation}

$A_{\mathrm{C}}$

$A_{\mathrm{g}}$

$A_{\mathrm{s}}$

$A_{\mathrm{t}}$

$A_{\text {tc }}$

$a_{\mathrm{s}}$

$D_{\text {c }}$

$D_{\mathrm{s}}$

$d_{\mathrm{c}}$

$E_{\text {c }}$

$E_{\text {eq }}$

$E_{\mathrm{s}}$

$f_{\mathrm{s}}$

$f\left(a_{\mathrm{s}}\right)$

$g(\beta)$

$H_{\mathrm{c}}$ cross-sectional area of a column total area of a column group including all individual columns and the soil between columns surface area of a column toe cross-sectional area of a column total cross-sectional area of all individual columns area replacement ratio, defined as the cross-sectional area of a column divided by the total cross-sectional area of a unit cell coefficient of consolidation of soft soil in the radial direction modified coefficient of consolidation of soft soil in the radial direction undrained shear strength of surrounding soft soil constrained modulus of a column constrained modulus of soil diameter of a column diameter of a unit cell elastic modulus of a column equivalent elastic modulus of a pier elastic modulus of soil side friction influence factor of the area replacement ratio influence factor of the improvement depth thickness of the column penetration zone
$H_{\mathrm{L}} \quad$ length of a column

$H_{1} \quad$ thickness of an equivalent layer

$h(\gamma) \quad$ influence factor of the applied pressure to soil strength ratio

improvement factor

tensile stiffness of a geosynthetic

$\begin{array}{ll}J & \text { tensile } \\ K & \text { factor }\end{array}$

$K_{\text {eq }} \quad$ stiffness of an equivalent pier

$K_{\mathrm{pr}} \quad$ stiffness of a pier-raft system

$K_{\mathrm{r}} \quad$ stiffness of a raft on the soil

$k_{\mathrm{c}} \quad$ permeability of a column

$k_{\mathrm{r}}, k_{\mathrm{v}} \quad$ permeability of soil in the radial and vertical directions

$k_{\mathrm{s}} \quad$ permeability of a smear zone

$m_{\mathrm{v} 1} \quad$ coefficient of the volumetric compressibility of an equivalent layer

$N$ diameter ratio, defined as the ratio of the influence diameter to the column diameter in a unit cell stress concentration ratio stress concentration ratio considering lateral deformation of a column

$P_{\text {eq }} \quad$ load carried by an equivalent pier

$P_{\mathrm{r}} \quad$ load carried by a raft

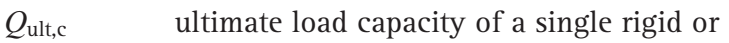
semi-rigid column 


\begin{tabular}{|c|c|}
\hline$q_{\mathrm{t}}$ & toe resistance \\
\hline$q_{\mathrm{u}}$ & $\begin{array}{l}\text { field unconfined compressive strength of a } \\
\text { column }\end{array}$ \\
\hline$q_{\text {ult }}$ & $\begin{array}{l}\text { ultimate bearing capacity of a flexible } \\
\text { column-reinforced composite foundation }\end{array}$ \\
\hline$q_{\text {ult,c }}$ & $\begin{array}{l}\text { ultimate bearing capacity of a single flexible } \\
\text { column }\end{array}$ \\
\hline$q_{\text {ult,s }}$ & ultimate bearing capacity of surrounding soil \\
\hline$r_{\mathrm{c}}$ & radius of a column \\
\hline$S$ & settlement of a composite foundation \\
\hline$S_{\mathrm{pr}}$ & settlement of a pier-raft system \\
\hline$S_{\mathrm{s}}$ & settlement of unreinforced soft soil \\
\hline$s$ & diameter ratio of a smear zone to a column \\
\hline$\alpha_{\mathrm{pr}}$ & pier-raft interaction factor \\
\hline$\beta$ & mobilisation factor of the bearing capacity of soil \\
\hline$\varepsilon_{z}$ & vertical strain at a depth of $z$ \\
\hline$\lambda$ & mobilisation factor of an end-bearing \\
\hline$v_{\mathrm{c}}, v_{\mathrm{s}}$ & Poisson ratios of column and soil, respectively \\
\hline$\sigma_{\mathrm{c}}$ & vertical stress on a column \\
\hline$\sigma_{\mathrm{c} x}, \sigma_{\mathrm{c} y}, \sigma_{\mathrm{c} z}$ & $\begin{array}{l}\text { stresses on a column in the } x, y \text { and } z \text { directions, } \\
\text { respectively }\end{array}$ \\
\hline$\sigma_{\mathrm{s}}$ & vertical stress on soil \\
\hline$\sigma_{\mathrm{s} x}, \sigma_{\mathrm{s} y}, \sigma_{\mathrm{s} z}$ & $\begin{array}{l}\text { stresses on soil in the } x, y \text { and } z \text { directions, } \\
\text { respectively }\end{array}$ \\
\hline$\phi_{\mathrm{c}}$ & friction angle of column material \\
\hline
\end{tabular}

\section{Introduction}

In geotechnical engineering, a column is a vertical sub-structural element, installed in situ by ground improvement techniques (replacement, displacement, or mixture with chemical agents), that transmits the load from a super structure or earth structure to underlying or surrounding geo-media through compression, shear, bending or rotation. Columns are mostly used to improve soft soils by increasing the bearing capacity, reducing total and differential settlements, accelerating consolidation and enhancing stability. Sometimes, columns are also used to densify loose deposits, such as sand, loess and collapsible soils, to minimise liquefaction and/or collapse potential. This paper will discuss only the column technologies used to improve soft foundations, which include soft clay, silt, clayey or silty soil and peat. Recently columns have been increasingly used to support embankments over soft foundations, especially when differential settlement and/or rate of construction are involved. Different types of columns have been used, which have different construction techniques, materials and rigidity. Composite columns have been developed to utilise the advantages of individual components of the columns. Columns have also been combined with other technologies, such as geosynthetic reinforcement, pre-fabricated vertical drains, concrete piles and so on, to improve their performance. This paper summarises different types of column technologies and their functions, installation and applications, addresses design issues, and reviews recent research and development related to the column technologies to improve soft foundations including failure modes, load transfer mechanisms, bearing capacity, settlement, consolidation and stability.

\section{Types of columns}

Internationally, the following columns have been commonly used in practice: sand compaction piles (columns) (SCPs), stone columns, deep mixed (DM) columns, grouted columns, and vibro-concrete columns (VCCs). Cement-fly ash-gravel (CFG) columns are commonly used in China, whereas rammed aggregate piers are commonly used in the USA. In recent years, geosynthetic-encased stone columns and controlled modulus columns have been increasingly used. In addition, new types of columns have been developed, such as hollow concrete columns (Liu et al., 2003), multiple stepped columns (Borel, 2007; Liu, 2007a), X-shape (Liu, 2007b) or Y-shape (Chen et al., 2010) concrete columns, grouted stone columns (Liu, 2007a) and Tshaped DM columns (Liu et al., 2012). Most of these new columns are concrete columns, which have higher strength and stiffness, but different shapes have been used to reduce the amount of concrete to create more efficient and economic solutions. Furthermore, columns have been installed in a composite form, as shown in Figure 1, which are referred to as composite columns. Composite columns take advantage of the positive effects of the individual components (e.g. concrete piles for strength and stiffness, and sand columns for drainage). Geosynthetic-encased stone columns, stiffened DM columns (Jamsawang et al., 2008) and composite spun piles (Bhandari and Han, 2009) are also composite columns. Chu et al. (2009) provided an excellent overview of different construction technologies in geotechnical engineering, including the column technologies. Among all the above columns, concrete columns have gained great acceptance in practice to improve very soft foundations, but limited research has been done and few design methods are available. Geosynthetic-encased stone columns have drawn great attention from researchers (e.g. Castro and Sagaseta, 2011a; Gniel and Bouazza, 2009; Khabbazian et al., 2010; Raithel and Kempfert, 2000; Raithel et al., 2005; Zhang et al., 2012); few field studies have been reported so far and most of the studies were limited to laboratory model tests and numerical analyses. Therefore, more research and field studies are needed for concrete columns and geosynthetic-encased stone columns.

Han and Ye (1991) proposed three methods to classify columns based on installation methods, column materials and column rigidity. These classification methods are still mostly valid after some modifications as listed in Table 1. Flexible columns have relatively lower load capacities and stiffness while rigid columns have higher load capacities and stiffness. Semi-rigid columns have load capacities and stiffness between flexible and rigid columns. An important characteristic of semi-rigid columns is that the capacities and stiffness of these columns vary with the type and properties of the inclusion in or around the columns, such as cement content and the stiffness of geosynthetic reinforcement. Composite columns with rigid or semirigid inclusions often behave like semi-rigid columns. The classification of the columns based on the installation methods has little to do with the other two classifications. However, the classifications of the columns based on column materials and 


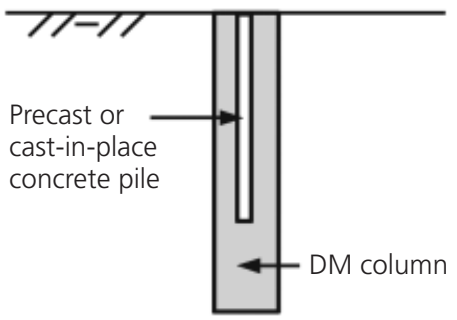

(a)

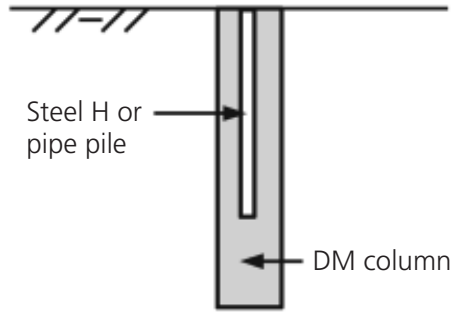

(b)

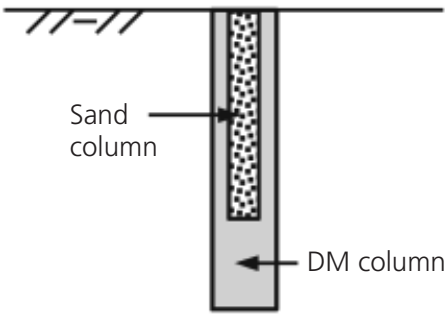

(c)

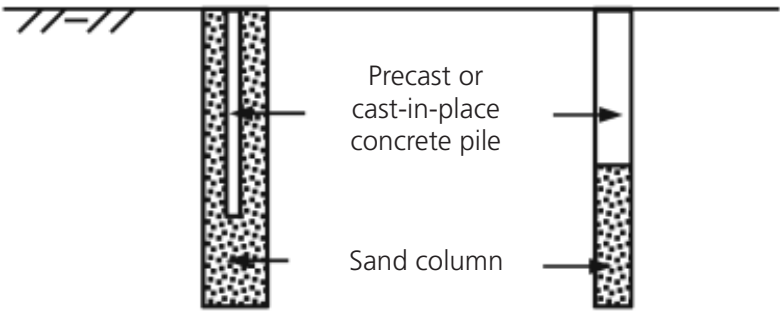

(d)

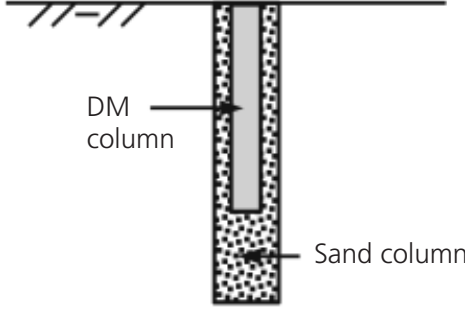

(e)

Figure 1. Composite columns (modified from Zheng et al. (2009a))

\begin{tabular}{lll}
\hline Method & Type & Technology examples \\
\hline Installation & Replacement & Stone columns \\
& Displacement & Sand compaction piles, stone columns \\
& Mixture & DM columns, grouted columns \\
& Combination & Rammed aggregate piers \\
Material & Granular & Sand compaction piles, stone columns, rammed aggregate piers \\
& Chemically stabilised & DM columns, grouted columns \\
& Concrete & Concrete columns, cement-fly ash-gravel (CFG) columns \\
Rigidity & Composite & Geosynthetic-encased soil columns, stiffened DM columns, composite spun piles \\
& Flexible & Sand compaction piles, stone columns, rammed aggregate piers \\
& Semi-rigid & DM columns, grouted columns, composite columns \\
& Rigid & Concrete columns
\end{tabular}

Table 1. Classification of columns

rigidity are interrelated. In this paper, the classification of the columns based on the material or rigidity will be adopted in the following discussion.

\section{Functions, installation and applications}

\subsection{Functions}

After installation, columns have served at least one of the following functions in geotechnical applications: load bearing, reinforcement, drainage and containment.

Owing to their higher strength and stiffness as compared with surrounding soils, columns often serve as load-bearing elements, carrying a large portion to most of the load from superstructures, and transmitting it to a deep competent layer or through side friction as piles; therefore, this is also referred to as a pile effect. This effect increases the bearing capacities and reduces the settlements of soft soils.

Analogously to steel-reinforced concrete, columns can also serve as reinforcements to soft soils in the composite foundation, in which soft soils are the matrix. In the composite foundation, columns and soils deform together to share the vertically applied load and/or provide shear resistance against sliding.

It is obvious that granular columns can serve as drainage paths to soft soils. Recent research showed that chemically stabilised and concrete columns can also accelerate the dissipation of excess pore water pressure in soft soils (e.g. Huang et al., 2009; Zheng 
et al., 2011). Han and Ye (2001) found that the acceleration of consolidation of stone-column-reinforced foundations is attributed to the drainage of the columns and the reduction of the vertical stresses on soft soils. The acceleration of consolidation of the composite foundation by low-permeability columns is mainly attributed to the reduction of the vertical stresses on soft soils. Composite columns, as shown in Figures 1(b) and 1(c), contain sand columns for drainage.

Chemically stabilised soil columns and concrete columns can have lower permeability than soft soils; therefore, they can be used as a containment barrier to water seepage during excavation or pollutants from contaminants when they are installed in a wall or block pattern.

Column-reinforced composite foundations as stiffened platforms have higher equivalent strengths and stiffness, which help distribute vertical loads to the underlying soft soils in a wider area and reduce the distributed vertical stresses onto the soft soils. As a result, possible failure of the underlying soft soil is prevented and its deformation is reduced.

\subsection{Installation}

Different methods are used to install columns, as shown in Table 1. They can be classified into four categories: $(a)$ replacement, (b) displacement, (c) mixture and (c) combination.

Replacement is to remove the in situ soil and backfill the hole with better material. The removal of the in situ soil can be accomplished by water jetting or drilling. The replacement method has little to no effect on the surrounding soil. Displacement involves displacing the in situ soil by high-pressure air, casing or ramming, and then backfilling the hole with better material. A combined method, such as partial replacement and displacement, involves the process of removing the in situ soil partially and then displacing the surrounding soil during the installation of the column. Instead of replacement and/or displacement, columns can also be formed by mixing a chemical agent with the in situ soil using mechanical (deep mixing) or hydraulic (grouting) means. Granular and concrete columns are mostly installed by a replacement and/or displacement method, whereas chemically stabilised soil columns are mostly installed by mixing.

Different installation methods have different effects on the surrounding soils. The effects also depend on the type of the surrounding soil and the level of the groundwater table. The replacement and mixing methods typically have limited to no effect on the surrounding soil. The displacement method typically has a significant effect on the surrounding soil, which can be densification and/or consolidation of the soil, ground heave, or a combination of these effects. In loose sands, densification can happen during the installation. In soft clays, however, large excess pore water pressure can be generated in the surrounding soil, and dissipation of the water pressure with time results in soil consolidation.

Debats et al. (2003) reported that the vertical and radial effective stresses in the surrounding soil within a radius of $5 \mathrm{~m}$ from the axis of the column increased with time after the installation of the stone columns by the displacement method in the field. Guetif et al. (2007) verified this field result in their numerical analysis. Experimental and numerical studies showed that the lateral expansion towards the surrounding soil by ramming aggregates in a pre-bored hole could increase the horizontal stresses in the soil, increase the load capacity of the column and reduce the settlement of the column (Chen et al., 2009). McCabe et al. (2013) reported that the installation of displacement stone columns could induce ground heave up to a distance of 20 times the radius of the column. Shen et al. (2008) showed that the strength of the surrounding sensitive clay by deep mixing first decreased and then mostly regained or even exceeded its original strength after column installation. Shen et al. (2008) attributed the property changes in the short term to the soil disturbance and fracturing and those in the long term to thixotropic hardening, consolidation and diffusion of ions from the hardening agent.

\subsection{Applications}

Columns have been used for many applications in soft soils: $(a)$ support of superstructures including buildings, walls, embankments and so on, (b) stabilisation of slopes, (c) lateral support and $(d)$ containment of water and pollutants. In these applications, columns are used to increase the bearing capacity, reduce settlement, enhance slope stability, provide lateral support, and contain water and pollutant movement.

In recent years, columns have been largely used to support embankments over soft foundations (Filz et al., 2012; Han and Gabr, 2002; Springman et al., 2014; Van Eekelen et al., 2013). This application is considered as one of the most important applications of column technologies in recent years. Columns have also been increasingly combined with other technologies, such as geosynthetic reinforcement, prefabricated vertical drains (PVDs) and rigid piles. Geosynthetic reinforcement above columns acts as a bridging layer to transfer the embankment load to the columns and to reduce the differential settlement between the columns. The common applications of geosynthetic-reinforced column-supported embankments are: $(a)$ bridge approaches, (b) roadway widening, $(c)$ subgrade improvement and $(d)$ the support of storage tanks (Han and Gabr, 2002). Concrete slabs have also been used above columns instead of geosynthetic reinforcement to support embankments over soft foundations (e.g. Zheng et al., 2011).

When embankments are constructed over thick, soft soils, the soft soils often do not have sufficient bearing capacity to support the embankments. Under such a condition, columns can be used to increase the bearing capacity of the soft foundation. Unless the soft soils within the influence depth are fully reinforced by 
columns (often requiring significantly long columns, which are costly), the soft soils below the reinforced zone at a greater depth still deform at a slow rate. To reduce the length of columns and to accelerate the rate of consolidation of the soft soils below the reinforced zone, $\mathrm{Xu}$ et al. (2006) proposed the use of DM columns to improve soft soils at a shallower depth and PVDs to accelerate the rate of consolidation at a greater depth. The concept of this combined technology is shown in Figure 2(a). A similar method was proposed by Liu et al. (2008), as shown in Figure 2(b) by combining dry jet mixed columns with PVDs; however, its primary purpose is to use PVDs to accelerate the dissipation of excess pore water pressure induced by dry jet mixing installation, thus minimising the installation disturbance. The secondary purpose of this combined technology is to accelerate the consolidation of the soft soil between the columns.

Short columns can also be used between long, rigid piles or long columns to increase the bearing capacity of soft soils at a shallower depth, thus reducing the loads carried by long, rigid piles or long columns so that the spacing of the long, rigid piles or long columns can be enlarged to create a more economical solution (Huang and Li, 2009; Zheng et al., 2009b). Figure 3 illustrates the concept of this combined method.

\section{Failure modes and load transfer mechanisms}

\subsection{Failure modes}

Columns have been mostly used to carry vertical loads. Sometimes, they are used to increase the shear resistance of soft foundations for deep-seated slope stability. Under certain circumstances, columns are subjected to horizontal loads or movement,

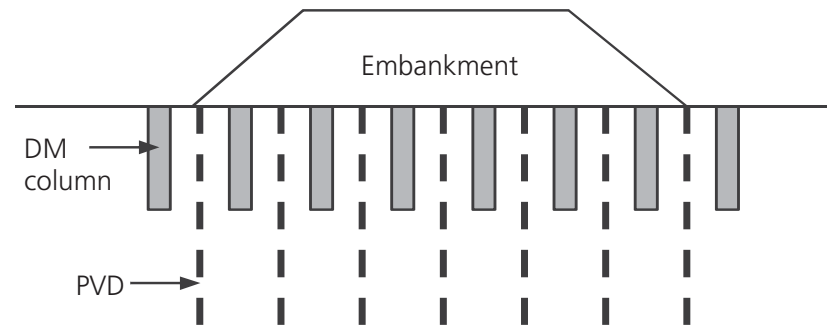

(a)

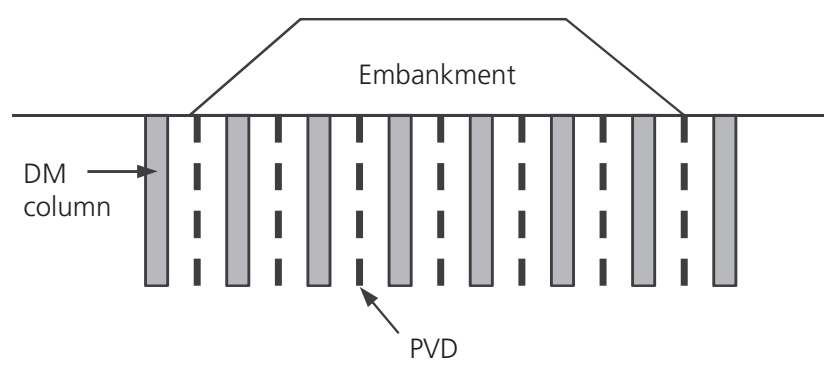

(b)

Figure 2. Deep mixed column-PVD combined method: (a) short columns and long PVDs; (b) equal-length columns and PVDs

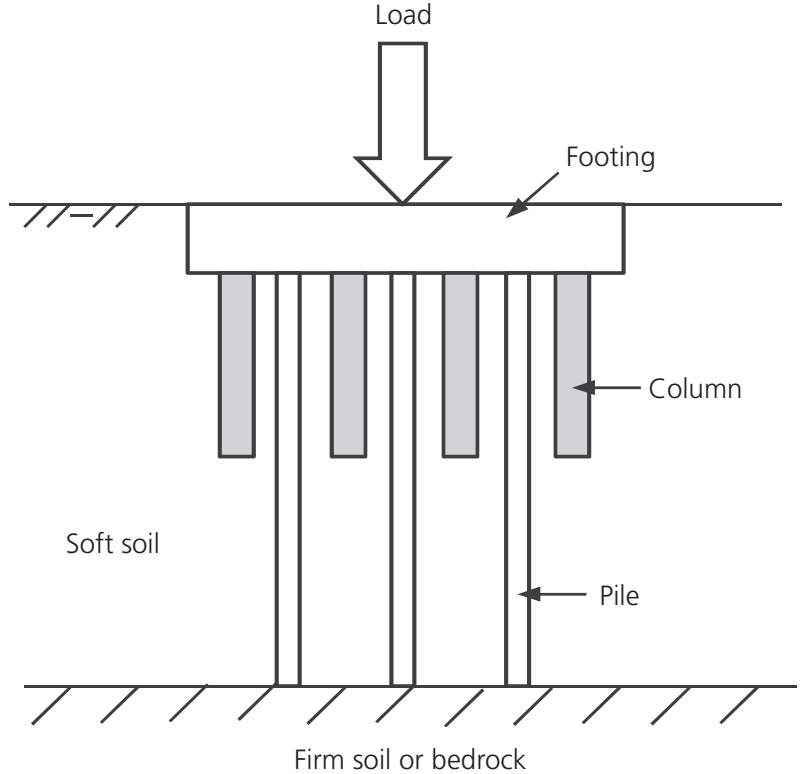

Figure 3. Column-pile combined method

for example during excavation or under embankments. The failure modes of the columns under these conditions are different.

Columns under a vertical compressive load transmit the load through the surrounding soil by side friction or lateral confinement. The possible failure modes are illustrated in Figure 4. Columns may crush when the applied load is higher than the strength of the columns. This failure more likely affects chemically stabilised columns, which have relatively brittle behaviour. Shear failure may affect granular columns or chemically stabilised columns at a low content of hardening agent. Punching failure may affect short, granular and chemically stabilised columns or concrete columns without an end-bearing layer. Bulging failure more likely affects granular columns in soft soils. Broms (1999) pointed out that columns may fail under tension when they are located under an embankment. Rammed aggregate piers have been used to provide uplift resistance by pre-installing a steel plate at the bottom of the pier (Farrell et al., 2008). For geosynthetic-encased columns, another possible failure mode is bursting of the geosynthetic reinforcement.

Columns under a horizontal load or movement provide shear resistance or a bending moment, and may fail under shear, bending or rotation. Shear failure may affect granular columns. Bending failure may affect long, chemically stabilised columns and concrete columns, especially when no steel reinforcement is included. Rotation may affect short, chemically stabilised columns and concrete columns. Rigid inclusions can be installed into granular or chemically stabilised columns to increase the shear and bending resistance of columns.

In column-supported embankments, columns are subjected not only to vertical compressive loads but also to horizontal loads; 


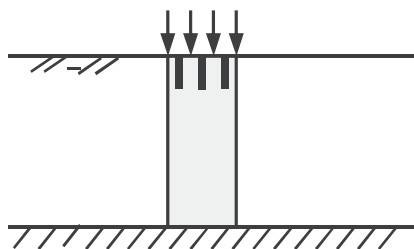

(a)

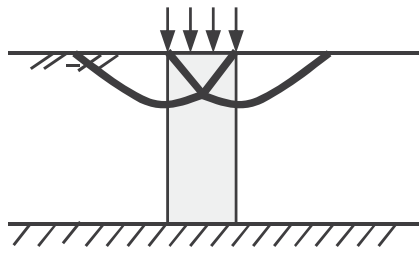

(b)

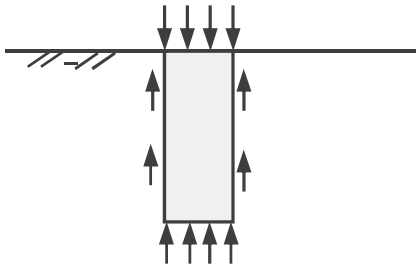

(c)

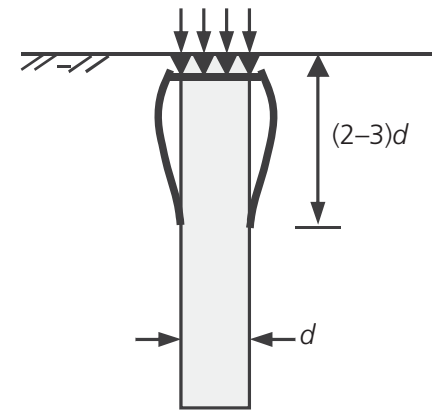

(d)

Figure 4. Possible failure modes of single columns subjected to vertical loads (modified from Han and Ye (1991)): (a) crushing failure; (b) shear failure; (c) punching failure; (d) bulging failure

therefore, they may fail under compression, tension, shear, bending and rotation (Broms, 1999; Filz and Navin, 2006; Han et al., 2005; Zheng et al., 2010a, 2010b).

\subsection{Load transfer mechanisms}

\subsubsection{Equal stress as opposed to equal strain}

In geotechnical analyses, there are two ideal boundary conditions: equal strain and equal stress. The equal-strain condition exists under rigid loading (e.g. rigid footing) whereas equal-stress exists under flexible loading (e.g. tyre pressure). In a column-reinforced soft foundation, columns carry a higher stress than the soil under an equal-strain (also equal settlement in the columns and the soil) condition due to the stiffness difference between columns and the surrounding soil (Figure 5). The ratio of the stress on the column $\left(\sigma_{\mathrm{c}}\right)$ to that on the soil $\left(\sigma_{\mathrm{s}}\right)$ is defined as the stress concentration ratio $(n)$, which is often used to describe the load transfer between columns and soft soils. However, under an equal stress condition, the columns and the soil carry the same stress (i.e. the stress concentration ratio is equal to 1) but have different

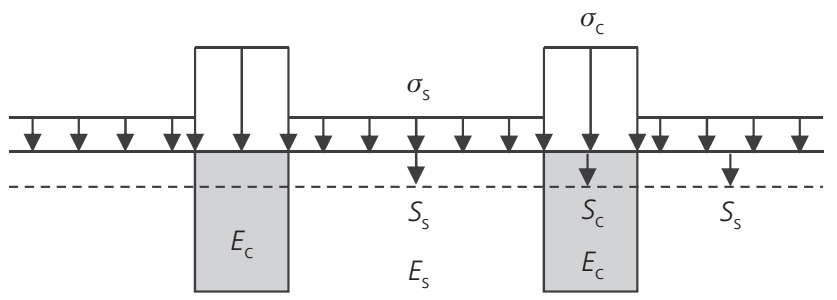

(a)

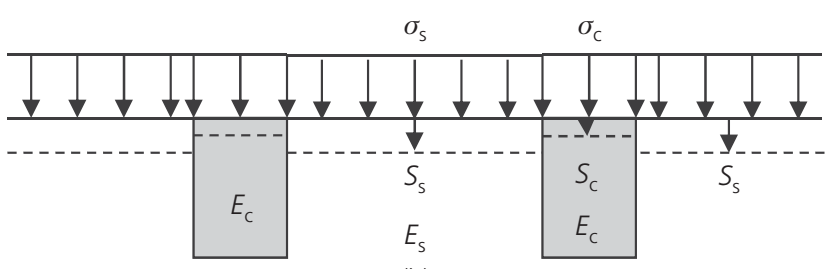

(b)

Figure 5. Equal strain plotted against equal stress: (a) equal strain = rigid loading; (b) equal stress = flexible loading settlements. As a result, there is a differential settlement between the columns and the soil. A column-supported embankment not only has a stress concentration ratio greater than 1.0 but also has a differential settlement (e.g. Han and Gabr, 2002; Huang et al., 2009). Therefore, a column-supported embankment has a condition between equal strain and equal stress.

\subsubsection{Unit cells without and with lateral deformation}

The unit cell, which consists of one column and its surrounding soil, has often been used to analyse column-reinforced soft foundations. A one-dimensional (1D) unit cell, which does not allow lateral deformation of the column as shown in Figure 6(a), has been mostly assumed by many researchers in their analyses in the past (e.g. Han and Ye, 2001, 2002; Xie et al., 2009a, 2009b). Han and Ye (2001) pointed out that an increase of a lateral stress from the column affected the variation of the excess pore water pressure in the surrounding soil. Castro and Sagaseta (2011b) and Jiang et al. (2013) found that the unit cell that allowed lateral deformation of the column as shown in Figure 6(b) affected the settlement and the consolidation rate of the column-reinforced soft foundations.

When a $1 \mathrm{D}$ unit cell is under an equal vertical strain condition, it has the following relationship

1a. $\varepsilon_{z}=\frac{\sigma_{\mathrm{c}}}{D_{\mathrm{c}}}=\frac{\sigma_{\mathrm{s}}}{D_{\mathrm{s}}}$

1b. $n=\frac{D_{\mathrm{c}}}{D_{\mathrm{s}}}$

where $\varepsilon_{z}$ is the vertical strain at a depth of $z ; \sigma_{\mathrm{c}}$ is the vertical stress on the column; $\sigma_{\mathrm{s}}$ is the vertical stress on the soil; $D_{\mathrm{c}}$ is the constrained modulus of the column; $D_{\mathrm{s}}$ is the constrained modulus of the soil; and $n$ is the stress concentration ratio. Therefore, the stress concentration ratio is equal to the constrained modulus ratio of the column to the soil under an equal vertical strain condition. 


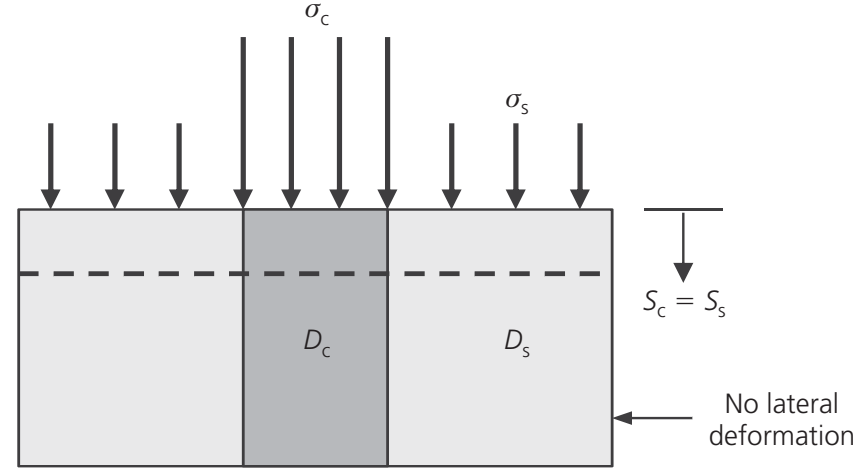

(a)

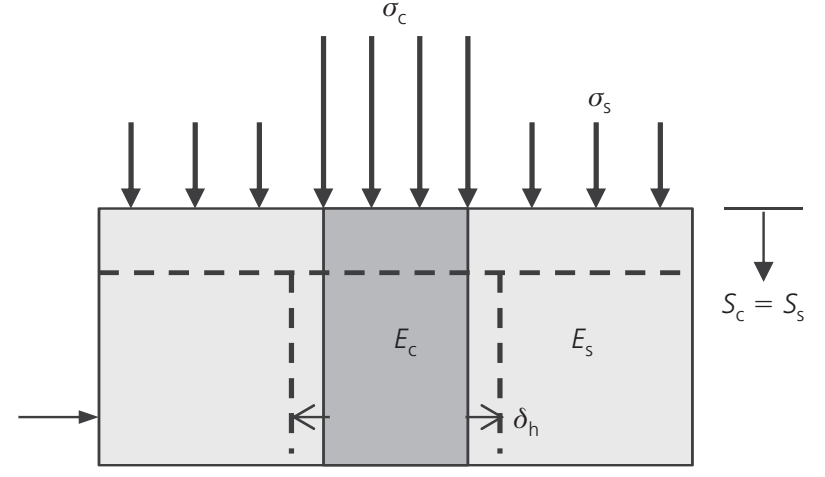

(b)

Figure 6. Unit cells without and with lateral deformation of column: (a) one-dimensional unit cell; (b) unit cell with lateral deformation

When a unit cell allowing lateral deformation is under an equal vertical strain condition, it has the following relationship

$$
\begin{aligned}
\varepsilon_{z} & =\frac{\sigma_{\mathrm{c} z}-v_{\mathrm{c}}\left(\sigma_{\mathrm{c} x}+\sigma_{\mathrm{c} y}\right)}{E_{\mathrm{c}}} \\
2 \mathrm{a} . \quad & =\frac{\sigma_{\mathrm{s} z}-v_{\mathrm{s}}\left(\sigma_{\mathrm{s} x}+\sigma_{\mathrm{s} y}\right)}{E_{\mathrm{s}}}
\end{aligned}
$$

2b. $\quad n^{\prime} \neq \frac{E_{\mathrm{c}}}{E_{\mathrm{s}}}$

where $\varepsilon_{z}$ is the vertical strain at a depth of $z ; \sigma_{\mathrm{c} x}, \sigma_{\mathrm{c} y}$ and $\sigma_{\mathrm{c} z}$ are the stresses on the column in the $x, y$ and $z$ directions, respectively; $\sigma_{\mathrm{s} x}, \sigma_{\mathrm{s} y}$ and $\sigma_{\mathrm{s} z}$ are the stresses on the soil in the $x, y$ and $z$ directions, respectively; $E_{\mathrm{c}}$ is the elastic modulus of the column; $E_{\mathrm{S}}$ is the elastic modulus of the soil; $\nu_{\mathrm{c}}$ and $v_{\mathrm{s}}$ are the Poisson ratios of the column and the soil, respectively; and $n^{\prime}$ is the stress concentration ratio considering lateral deformation of the column. Therefore, the stress concentration ratio is not equal to the elastic modulus ratio of the column to the soil under an equal vertical strain condition when column lateral deformation is allowed. Since the column under a concentrated stress deforms laterally towards the surrounding soil, the column with the lateral deformation carries less vertical stress but the surrounding soil carries more vertical stress than those in the 1D unit cell, respectively. As a result, the stress concentration ratio considering column lateral deformation is lower than that without considering lateral deformation. Figure 7 shows that the stress concentration ratio with no lateral deformation at the end of consolidation was equal to the elastic modulus ratio of the column to the soil. The stress concentration ratio with an elastic column (i.e. allowing lateral deformation) was lower than that with no lateral deformation.

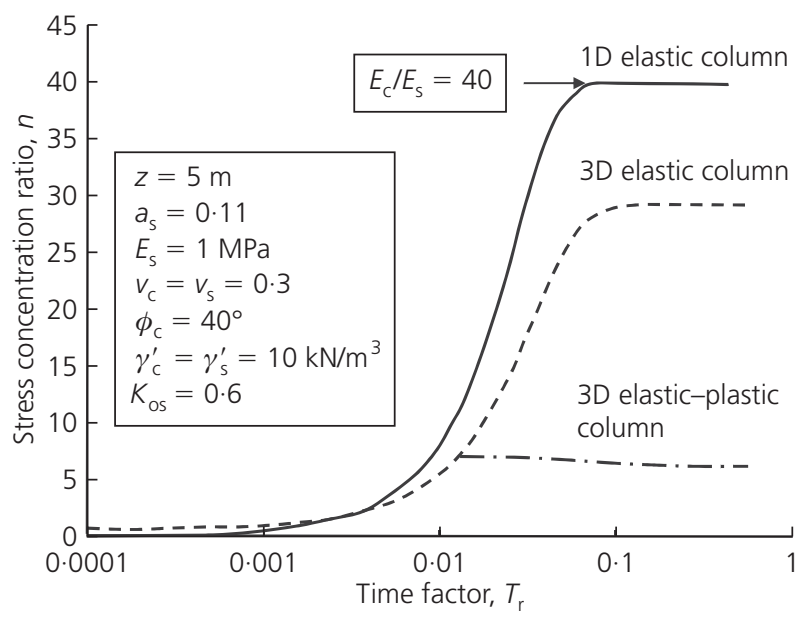

Figure 7. Stress concentration ratio under different conditions (modified from Castro and Sagaseta (2011b))

Since columns and soils have different stress-strain relationships, the stress concentration ratio, $n$, is not constant and depends on the properties of columns and soils and the stress or strain level. Figure 8 shows that the stress concentration ratio first increases with the strain and then decreases with the strain after the column yields. The increase of the stress concentration ratio indicates the stress transfer from the soil to the column, while the decrease of the ratio indicates the stress transfer from the column to the soil. For flexible columns, the columns and the soft soil may yield at a similar strain level. For semi-rigid and rigid columns, however, the columns often fail first before the soil mobilises its strength. Figure 7 shows that the foundation with elastic-plastic columns had a lower stress concentration ratio than that with elastic columns. Figure 7 also shows that the stress concentration ratio increased with time due to consolidation but decreased after the column yielded. These findings are the same as those of Han and Ye (2001) and Jiang et al. (2013). 

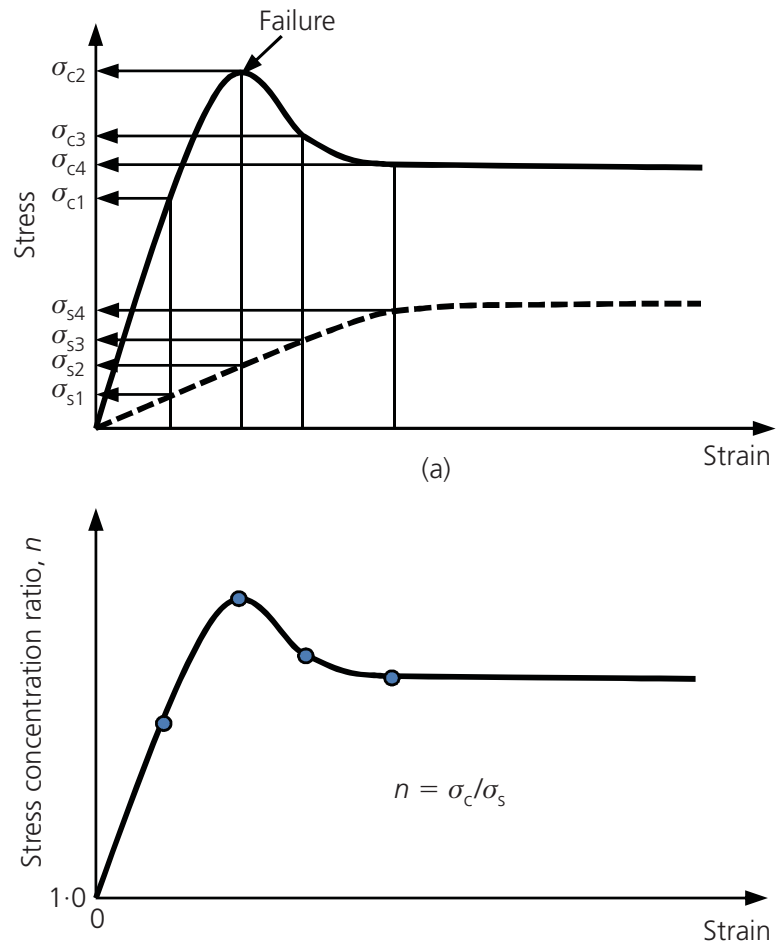

(b)

Figure 8. Stress concentration ratio at different strains: (a) stressstrain relationship; (b) stress concentration ratio

\subsubsection{Stress transfer under unequal vertical strain}

Simon and Schlosser (2006) clearly illustrated the load transfer and deformations in column-supported embankments in Figure 9. There exist two equal settlement planes in the system, one in the embankment fill and one in the soft soil, if the embankment height is higher than the critical height. Based on the field measurements, Chen et al. (2010) reported the critical heights in the embankments were in the range of $1 \cdot 0-1.5$ times the clear spacing of the piles. Based on the model and field tests, Filz et al. (2012) developed a relationship for the critical height with the diagonal clear spacing and the diameter of the columns. Owing to the relative difference between the pile settlement $\left(S_{\mathrm{c}}\right)$ and the soft soil settlement $\left(S_{\mathrm{s}}\right)$, the negative shear stress $(\tau)$ develops along the column between the upper and lower equal settlement planes but the positive shear stress develops below the lower equal settlement plane. The negative shear stress increases the average vertical stress $\left(\sigma_{\mathrm{c}}\right)$ in the column and reduces the average vertical stress $\left(\sigma_{\mathrm{s}}\right)$ in the soft soil, which is higher than the initial overburden stress $\left(\sigma_{0}\right)$ but lower than the average vertical stress $\left(\sigma_{\mathrm{f}}\right)$ with fill surcharge. Figure 9 also shows that the stress concentration ratios at different depths are different. The vertical stresses above the column and the soil at the upper equal settlement plane are equal, while the highest stress concentration on the column exists at the lower equal-settlement plane. This load transfer mechanism was included in the analytical model proposed by Chen et al. (2008).

The measured stress concentration ratios from several field tests are presented in Figure 10. It is shown that the stress concentration ratio increased from 1.0 to a certain value with the applied pressure and then decreased after reaching the peak value. The peak stress concentration ratio occurred when the column stress reached the yield strength. After the column yielded, the stress on the column transferred back to the soil until both yielded and reached their constant values. Figure 10 shows that the columnsupported embankment (CSE) without geosynthetic reinforcement had a lower stress concentration ratio. The inclusion of geosynthetic reinforcement increased the stress concentration ratio,

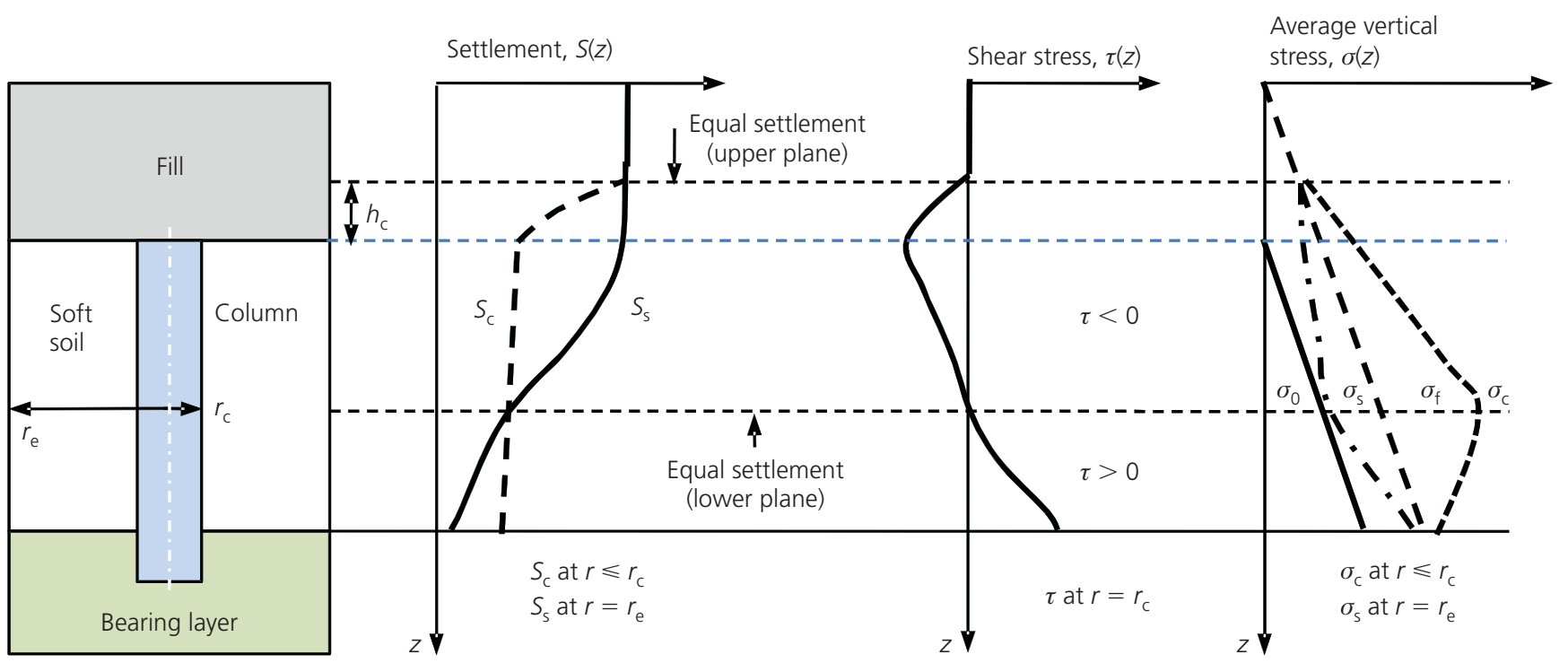

Figure 9. Stress transfer in a column-supported embankment (modified from Simon and Schlosser (2006)) 


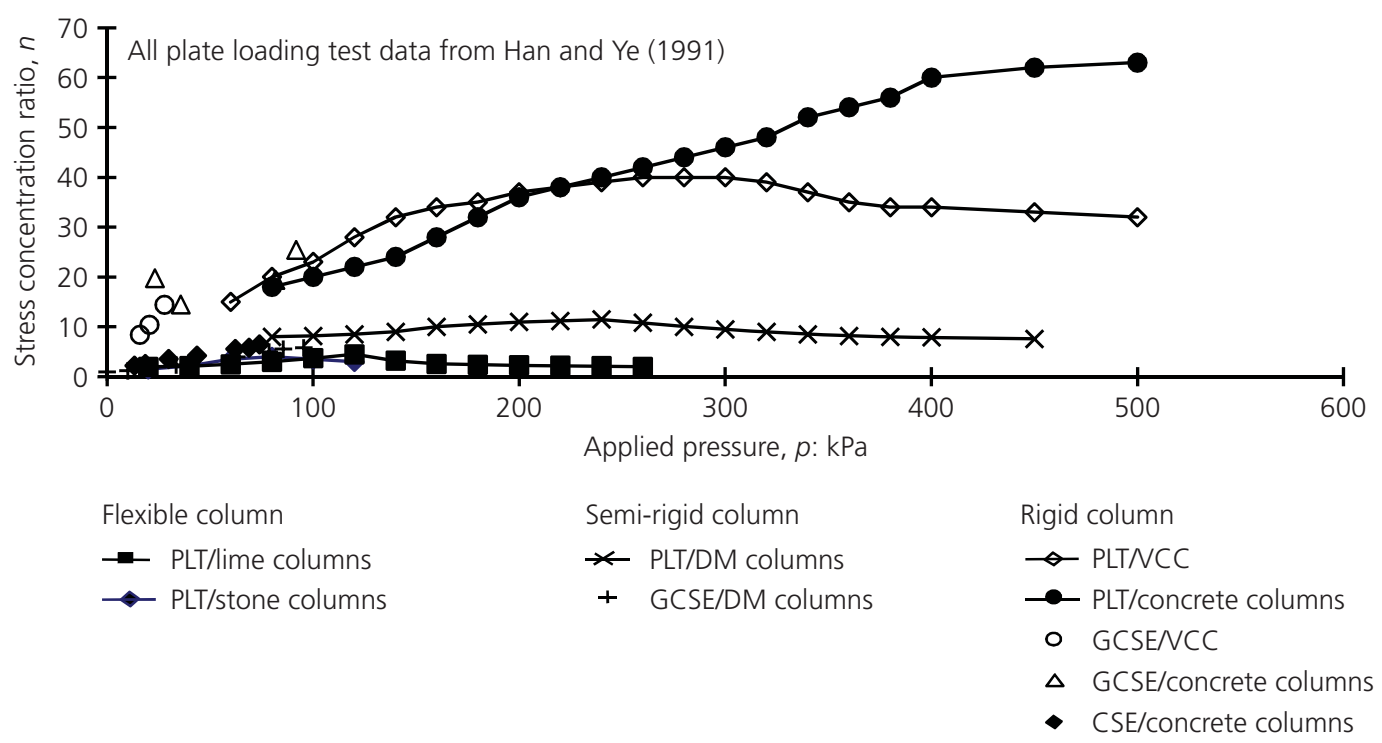

Figure 10. Measured stress concentration ratios in field (after

Han and Wayne (2000)) (PLT, plate loading test)

which was confirmed by the numerical analysis (Han and Gabr, 2002) and the field measurements (Briançon and Simon, 2012). Figure 10 also shows that the flexible columns had stress concentration ratios from 1.0 to $5 \cdot 0$, the semi-rigid columns had ratios from $5 \cdot 0$ to 10.0 , and the rigid columns had ratios more than 10.0 when they were under rigid loading plates or in geosynthetic-reinforced column-supported embankments (GCSEs). Zheng et al. (2012) reported a similar variation of the stress concentration ratio from 8.0 to 16.0 measured below the geogrid reinforcement and on the top of concrete pile caps supported by concrete piles under the embankment loading.

\section{Design issues}

In general, flexible and semi-rigid column-reinforced foundations are designed as composite foundations whereas rigid columns are designed as piles. In the composite foundation design, a unit cell concept is often used for simplification. This paper addresses the following design issues: (a) bearing capacity, (b) settlement, (c) consolidation and $(d)$ stability, based on the rigidity of columns.

\subsection{Bearing capacity}

The bearing capacities of column-reinforced soft foundations have been evaluated using three methods: $(a)$ single column, (b) unit-cell composite foundation and (c) group columns. The unit cell composite foundation consists of a column surrounded by the soil, and its bearing capacity is contributed by the column and the surrounding soil.

\subsubsection{Flexible columns}

The ultimate bearing capacity $\left(q_{\text {ult,c }}\right)$ of a single flexible column mainly depends on the friction angle of granular material and the lateral confinement related to the undrained shear strength $\left(c_{\mathrm{u}}\right)$ of the surrounding soft soil. Brauns (1978) derived a theoretical solution for calculating the ultimate bearing capacity of a single stone column; other solutions have also been obtained by different researchers (e.g. Hughes and Withers, 1974). These solutions for the ultimate bearing capacity of a single stone column can be simplified into the following format

3. $q_{\mathrm{ult}, \mathrm{c}}=K c_{\mathrm{u}}$

where $K$ is a factor, varying from 15 to 25 with an average of 20 (Ye et al., 1994). The $K$ factor mainly depends on the quality of the column material. The higher-quality column material has a larger $K$ value.

Since flexible columns and the surrounding soil mobilise their strengths at a similar strain level, the ultimate bearing capacity $\left(q_{\mathrm{ult}}\right)$ of a flexible column-reinforced composite foundation can be estimated as follows

4. $\quad q_{\mathrm{ult}}=q_{\mathrm{ult}, \mathrm{c}} a_{\mathrm{s}}+q_{\mathrm{ult}, \mathrm{s}}\left(1-a_{\mathrm{s}}\right)$

where $q_{\text {ult,s }}$ is the ultimate bearing capacity of the surrounding soil. In the unit cell, an area replacement ratio $\left(a_{\mathrm{s}}\right)$ is defined as the cross-sectional area of the column divided by the total crosssectional area of a unit cell. The ultimate bearing capacity of the column, $q_{\text {ult,c, }}$, can be estimated using Equation 3; however, this estimation is conservative because the vertical stress on the surrounding soil is not considered in Equation 3.

Bouassida et al. (1995) developed a theoretical solution for the 
bearing capacity of a foundation on a soil reinforced by a group of columns.

\subsubsection{Rigid columns}

The ultimate load capacity $\left(Q_{\mathrm{ult}, \mathrm{c}}\right)$ of a single, rigid column can be estimated using the same method for a single, rigid pile, that is

5. $Q_{\mathrm{ult}, \mathrm{c}}=f_{\mathrm{s}} A_{\mathrm{s}}+q_{\mathrm{t}} A_{\mathrm{t}}$

where $f_{\mathrm{s}}$ is the side friction, $q_{\mathrm{t}}$ is the toe resistance, $A_{\mathrm{s}}$ is the surface area of the column and $A_{\mathrm{t}}$ is the toe cross-sectional area of the column. For some rigid columns, for example, VCCs, the toe cross-sectional area is larger than the column shaft crosssectional area.

The ultimate bearing capacity $\left(q_{\text {ult }}\right)$ of a rigid column-reinforced composite foundation can be estimated using the method proposed by Poulos (2001) for a piled raft foundation, which is the lesser of the following two load capacities: (a) the sum of the load capacities of the raft and all the rigid columns and $(b)$ the sum of the load capacities of the equivalent pier and the raft outside the periphery of the pier.

\subsubsection{Semi-rigid columns}

Semi-rigid columns have a behaviour between flexible and rigid columns. The ultimate load capacity of a single semi-rigid column depends on the strength of the column, the side friction between the column and the soil, and the toe resistance of the column. The ultimate load capacity $\left(Q_{\text {ult,c }}\right)$ of a single semi-rigid column can be estimated as the lesser of the following two capacities (Han et al., 2002)

\section{6. $Q_{\mathrm{ult}, \mathrm{c}}=q_{\mathrm{u}} A_{\mathrm{c}}$}

7. $Q_{\mathrm{ult}, \mathrm{c}}=f_{\mathrm{s}} A_{\mathrm{s}}+\lambda q_{\mathrm{t}} A_{\mathrm{t}}$

where $q_{\mathrm{u}}$ is the field unconfined compressive strength of the column, $A_{\mathrm{c}}$ is the cross-sectional area of the column and $\lambda$ is the mobilisation factor of the end-bearing (typically ranging from $0 \cdot 4$ to $0 \cdot 6$ ). For chemically stabilised columns, the field strength is typically $20-50 \%$ of the laboratory strength.

The ultimate bearing capacity of a semi-rigid column composite foundation $\left(q_{\text {ult }}\right)$ can be calculated as follows (Han et al., 2002)

8. $q_{\mathrm{ult}}=a_{\mathrm{s}} \frac{Q_{\mathrm{ult}, \mathrm{c}}}{A_{\mathrm{c}}}+\beta\left(1-a_{\mathrm{s}}\right) q_{\mathrm{ult}, \mathrm{s}}$

where $\beta$ is the mobilisation factor of the bearing capacity of the soil, typically varying from 0.5 to $1 \cdot 0$ for frictional columns or
$0 \cdot 1$ to $0 \cdot 4$ for end-bearing columns. As shown in Figure 8 , the soil does not mobilise its full strength when the column fails. The mobilisation factor is to account for this fact.

For a geosynthetic-encased column, the additional strength provided by the geosynthetic hoop strength should be included, in addition to the lateral confinement from the surrounding soil for flexible columns (Raithel and Kempfert, 2000). Gniel and Bouazza (2009) showed that the isolated partially encased stone columns failed by bulging below the level of encasement.

\subsection{Settlement}

\subsubsection{Flexible columns}

Han (2010) summarised the methods for calculating the settlement of stone column-reinforced foundations, which are also generally valid for other flexible columns, including $(a)$ the stress reduction method, $(b)$ the improvement factor method and $(c)$ the elastic-plastic method.

Stress reduction method: the stress reduction method was proposed by Aboshi et al. (1979) as follows

9. $S=\frac{1}{1+a_{\mathrm{s}}(n-1)} S_{\mathrm{s}}$

where $S$ is the settlement of the composite foundation and $S_{\mathrm{s}}$ is the settlement of the unreinforced soft soil. Barksdale and Bachus (1983) developed a design chart to determine the stress concentration ratio for a stone-column-reinforced foundation, which can be approximated as (Han, 2010)

10.

$$
n=1+0 \cdot 217\left(\frac{E_{\mathrm{c}}}{E_{\mathrm{s}}}-1\right)
$$

where $E_{\mathrm{c}}$ is the elastic modulus of the column and $E_{\mathrm{s}}$ is the elastic modulus of the soil. Based on field data, the modulus ratio $\left(E_{\mathrm{c}} / E_{\mathrm{s}}\right)$ should be limited to 20 .

Improvement factor method: Priebe (1995) proposed a basic improvement factor method to calculate the settlement of stone column-reinforced soft foundations by a vibro-replacement method considering stiff and incompressible columns with a bulging over the column length as follows

$\begin{aligned} S & =\frac{1}{I_{\mathrm{f}}} \\ \text { 11. } \quad I_{\mathrm{f}} & =1+a_{\mathrm{s}}\left[\frac{5-a_{\mathrm{s}}}{4\left(1-a_{\mathrm{s}}\right) \tan ^{2}\left(45^{\circ}-\phi_{\mathrm{c}} / 2\right)}-1\right]\end{aligned}$

where $I_{\mathrm{f}}$ is the improvement factor and $\phi_{\mathrm{c}}$ is the friction angle of the column material. Priebe (1995) also suggested consideration 
of the column compressibility and overburden pressure in addition to the basic improvement factor. The formulae and design charts for such a consideration can be found in Priebe (1995).

Elastic-plastic method: Pulko and Majes (2005) and Castro and Sagaseta (2009) proposed methods to calculate the settlement of a stone column-reinforced soft foundation based on elasticplastic constitutive models. In their methods, the soft soil is assumed to be linearly elastic, whereas the stone columns are assumed to be linearly elastic-perfectly plastic following the Mohr-Coulomb failure criterion with a constant dilatancy angle. The plasticity starts with the upper portion of the column and can extend deeper to the whole length of the column with an increase of the applied load. Among these methods, Priebe's (1995) is still the favoured method to estimate the settlement of stone columnreinforced soft foundations in practice (McCabe and Egan, 2010; Douglas and Schaefer, 2014).

\subsubsection{Rigid columns}

The settlement of rigid column-reinforced soft foundations can be estimated using methods for piled rafts or pile groups. Horikoshi and Randolph (1999) and Poulos (2001) proposed simplified design methods to calculate the settlement of piled rafts, which are both based on pile-raft interaction. Horikoshi and Randolph (1999) used the equivalent pier concept for the piled raft method, as shown in Figure 11. In this method, the equivalent elastic modulus can be calculated by

$$
\text { 12. } E_{\mathrm{eq}}=E_{\mathrm{s}}+\left(E_{\mathrm{c}}-E_{\mathrm{s}}\right) \frac{A_{\mathrm{tc}}}{A_{\mathrm{g}}}
$$

where $E_{\mathrm{eq}}$ is the equivalent elastic modulus of the pier, $E_{\mathrm{c}}$ is the elastic modulus of the column, $E_{\mathrm{s}}$ is the elastic modulus of the soil, $A_{\mathrm{tc}}$ is the total cross-sectional area of all individual columns, and $A_{\mathrm{g}}$ is the total area of the column group including all individual columns and the soil between columns.

The stiffness of the pier-raft system in Figure 11(b) can be calculated by

\section{3.}

$$
K_{\mathrm{pr}}=\frac{P_{\mathrm{eq}}+P_{\mathrm{r}}}{S_{\mathrm{pr}}}=\frac{K_{\mathrm{eq}}+K_{\mathrm{r}}\left(1-2 \alpha_{\mathrm{pr}}\right)}{1-\left(K_{\mathrm{r}} / K_{\mathrm{eq}}\right) \alpha_{\mathrm{pr}}^{2}}
$$

where $K_{\mathrm{pr}}$ is the stiffness of the pier-raft system, $P_{\text {eq }}$ is the load carried by the equivalent pier, $P_{\mathrm{r}}$ is the load carried by the raft, $S_{\mathrm{pr}}$ is the settlement of the pier-raft system, $K_{\mathrm{eq}}$ is the stiffness of the equivalent pier, $K_{\mathrm{r}}$ is the stiffness of the raft on the soil and $\alpha_{\mathrm{pr}}$ is the pier-raft interaction factor. The settlement of the column-reinforced soft foundation, $S_{\mathrm{pr}}$, can be calculated based on the stiffness of the pier-raft system, $K_{\mathrm{pr}}$, and the total applied load (i.e. $P_{\text {eq }}+P_{\mathrm{r}}$ ).

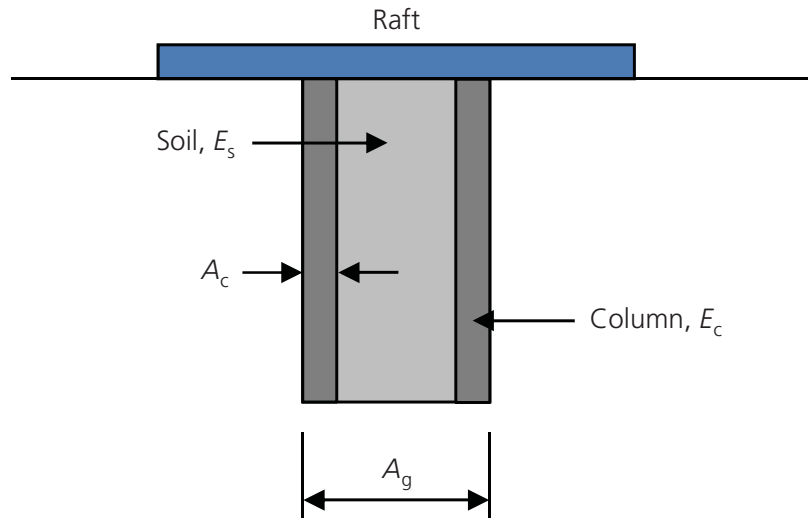

(a)

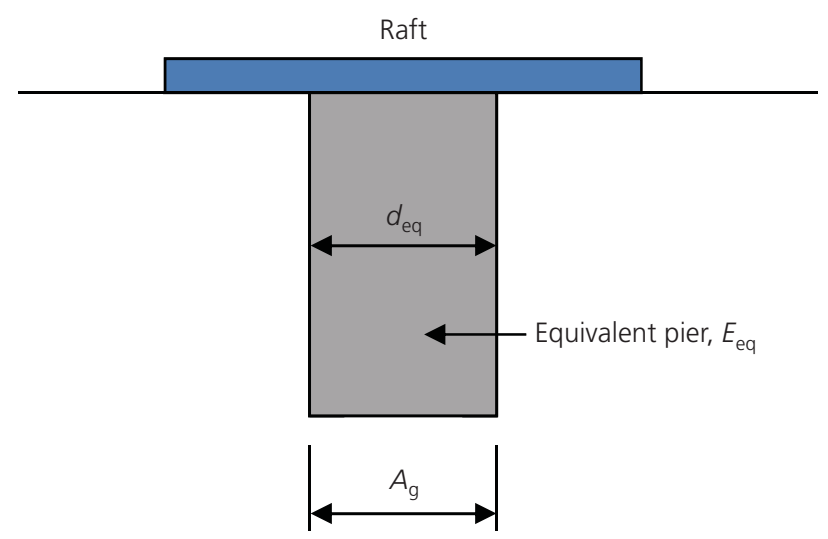

(b)

Figure 11. Equivalent pier in the piled raft method: (a) column group; (b) equivalent pier

The stress distribution method for pile groups included in Aashto (2006) can also be used for this purpose.

\subsubsection{Semi-rigid columns}

Owing to the characteristics of semi-rigid columns, the methods for flexible or rigid columns may be used to estimate the settlement of semi-rigid column-reinforced soft foundations, depending on the column rigidity. Jiang et al. (2013) showed that the stress reduction method calculated the settlement of the DM column-reinforced foundation close to the numerical result with less than $10 \%$ error. Khabbazian et al. (2010) showed numerically that the geosynthetic encasement significantly reduced the lateral displacement of the stone column. Raithel et al. (2005) showed that the improvement factors for geotextile-encased columnreinforced foundations were significantly increased by the tensile stiffness of the geotextile as compared with those for the stone columns without geotextile encasement. Castro and Sagaseta (2011a) modified their elastic-plastic solution for stone columns by considering the encasement of a geosynthetic to estimate the settlement of encased stone column-reinforced foundations. They found that the effect of geosynthetic encasement became important when the column started to yield, and its effectiveness 
depended on the geosynthetic stiffness factor, $J /\left(r_{\mathrm{c}} E_{\mathrm{s}}\right)$, in which $J$ is the tensile stiffness of the geosynthetic, $r_{\mathrm{c}}$ is the radius of the column and $E_{\mathrm{S}}$ is the soil modulus.

Han et al. (2009) verified that the method proposed by Horikoshi and Randolph (1999) for piled rafts can also be used to calculate the settlement of DM column-reinforced soft foundations. Since the Horikoshi and Randolph (1999) method does not consider lateral deformation of the columns, it should not be used for flexible columns because of their relatively large lateral deformations.

Chai et al. (2010) and Pongsivasathit et al. (2013) proposed a method to calculate the settlement of DM column-reinforced foundations underlain by a soft soil, in which the penetration of the columns was considered by treating the lower portion of the reinforced zone as an 'unreinforced' layer, as shown in Figure 12. Chai et al. (2010) and Pongsivasathit et al. (2013) obtained a simplified formula to estimate the thickness of the "unreinforced layer', which depends on the area replacement ratio, the improvement depth ratio (i.e. the column depth divided by the thickness of the soft soil) and the pressure-strength ratio as follows

\section{4. $H_{\mathrm{c}}=H_{\mathrm{L}} f\left(\alpha_{\mathrm{s}}\right) g(\beta) h(\gamma)$}

where $H_{\mathrm{c}}$ is the thickness of the column penetration zone (treated as an 'unreinforced' layer), $H_{\mathrm{L}}$ is the length of the column, $f\left(a_{\mathrm{s}}\right)$ is the influence factor of the area replacement ratio, $g(\beta)$ is the influence factor of the improvement depth and $h(\gamma)$ is the influence factor of the applied pressure to soil strength ratio. The settlement within the improved zone is calculated based on the

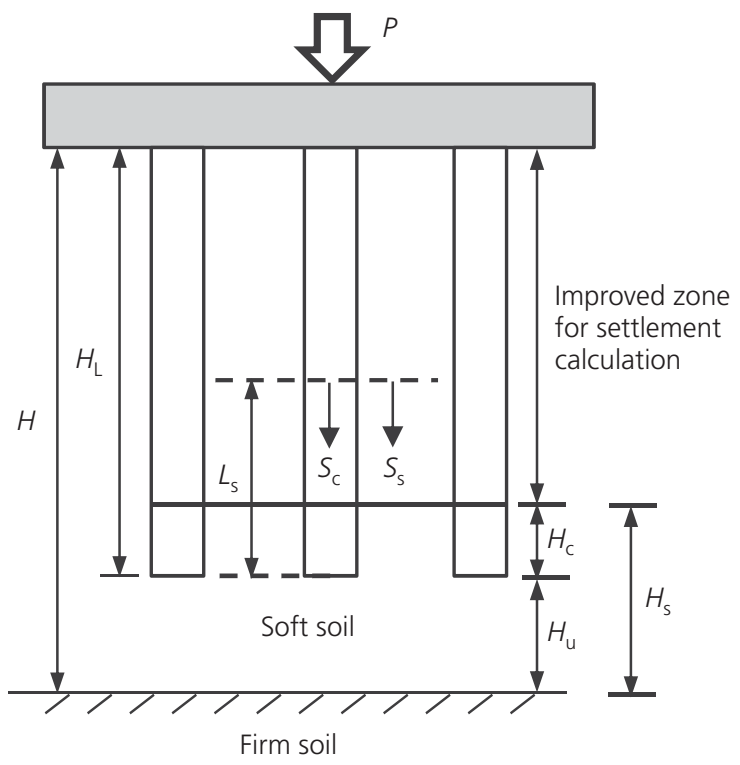

Figure 12. Column penetration method (modified from Chai et al. (2010)) compression of the composite foundation while the settlement below the improved zone (including the penetration zone) is calculated using the stress distribution method for pile groups included in Aashto (2006).

\subsection{Consolidation}

\subsubsection{Flexible columns}

Han and Ye $(2001,2002)$ developed simplified solutions for the consolidation rates of stone column-reinforced soft foundations without and with well resistance and smear effects, as shown in Figure 13. These solutions were developed based on the assumptions of equal strain and 1D deformation of the column and the soil in a unit cell. The modified coefficient of consolidation of soft soil in the radial direction was introduced and is presented below

15. $c_{\mathrm{rm}}=c_{\mathrm{r}}\left(1+n \frac{1}{N^{2}-1}\right)=c_{\mathrm{r}}\left(1+n \frac{a_{\mathrm{s}}}{1-a_{\mathrm{s}}}\right)$

where $c_{\mathrm{r}}$ is the coefficient of consolidation of soft soil in the radial direction, $c_{\mathrm{rm}}$ is the modified coefficient of consolidation of soft soil in the radial direction and $N$ is the diameter ratio, defined as the ratio of the influence diameter to the column diameter in a unit cell. The modified coefficient of consolidation of soft soil accounts for the contribution of the stress concentration on the columns due to the modulus difference between the column and the soil. The modified coefficient of consolidation of soft soil in the radial direction can be used to calculate the time factors for radial consolidation. Han and Ye (2001) concluded that the rate of pore water pressure dissipation or consolidation is contributed not only by the drainage of the column but also by the stress reduction on the soft soil.
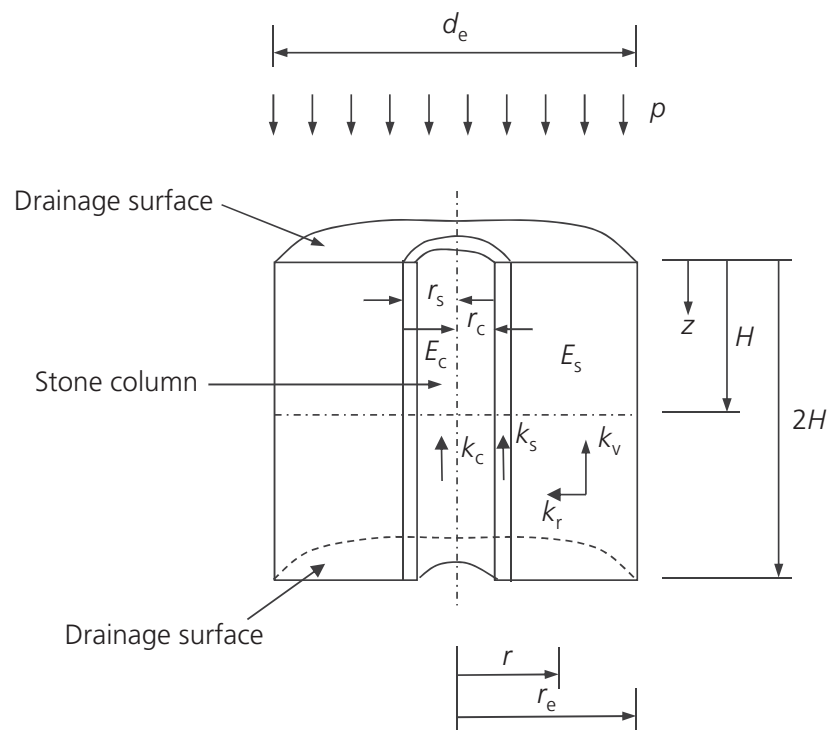

Figure 13. Unit cell model for stone column-reinforced soft foundations 
Baez and Martin (1995) and Boulanger et al. (1998) indicated that the intrusion of native soil into stone columns during field installation could reach $20 \%$ by weight. Field injection tests indicated the ratio of the permeability of stone columns to that of the native soil ranging from 15 to 40 , while laboratory tests indicated this ratio was from 40 to 100 . Han (2010) suggested the use of the formula for the permeability of a granular drain with fine contents in the Federal Highway Administration Highway Subdrainage Design manual (Moulton, 1980) to estimate the permeability of granular columns. Han (2010) found that the solution considering the well resistance effect predicted the rate of settlement better as compared with the field data than the solution without any well resistance, as shown in Figure 14.

Xie et al. (2009b) derived a solution for the rate consolidation of a stone column-reinforced foundation considering the variation of the permeability of the surrounding soil from the interface between the column and the surrounding soil to the boundary of a unit cell. Determination of such variations in the field is a challenging task. Xie et al. (2009a) also considered a step or ramp loading situation, which is useful to simulate the construction load, such as the filling of an embankment. In addition to a step or ramp loading, Wang (2009) developed a solution for the rate of consolidation for the stone column-reinforced foundation subjected to a cyclic loading, which may be useful to simulate traffic loading. Both Xie et al. (2009a) and Wang (2009) compared their solutions to that of Han and Ye (2002) under an instantaneous load, and obtained good agreement. All the abovementioned solutions were developed based on the assumptions of equal strain and 1D vertical elastic deformation in the column and the soil.

Castro and Sagaseta (2009) developed their solutions considering lateral deformation of stone columns under a vertical load. The lateral deformation of the column reduces the load carried by the column and slows down the rate of consolidation. In addition, Castro and Sagaseta (2009) treated the stone column as a linearly

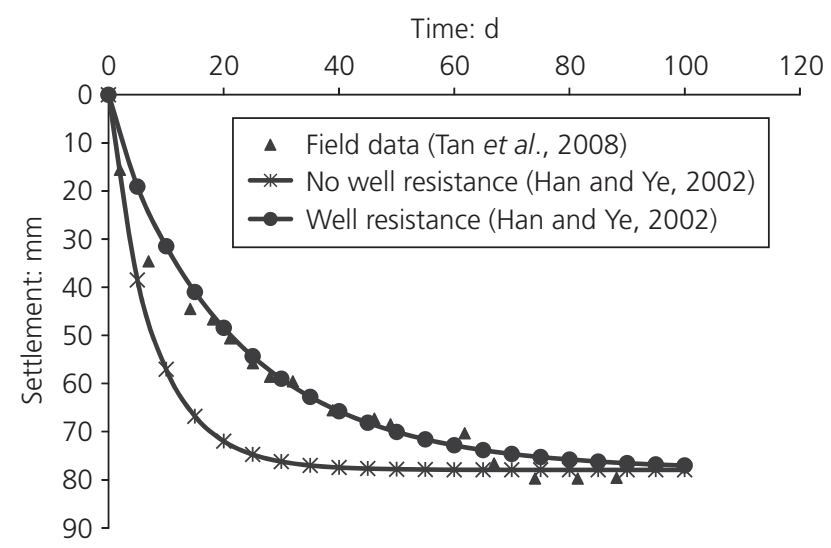

Figure 14. Rate of settlement with or without well resistance (after Han (2010)) elastic-perfectly plastic material. The upper portion of the column can yield under a certain load and the plastic zone can extend deeper to the whole length of the column when the applied load is increased. They also developed modified coefficients of consolidation based on elastic and plastic deformations. However, the Castro and Sagaseta (2009) solutions did not consider smear and well resistance effects on the rate of consolidation of the stone column-reinforced foundation.

\subsubsection{Rigid columns}

The rate of consolidation of rigid column-reinforced foundations with an end-bearing condition should not be affected because the rigid columns carry a majority of the load, and the settlement occurs immediately. When rigid columns partially penetrate into the soft soil, the rate of consolidation can be an issue. Zheng et al. (2011) showed that the excess pore water pressure in the soft clay between CFG rigid columns dissipated rapidly after each embankment loading. Research is needed to develop a solution for the rate of consolidation of rigid column-reinforced foundations with partial column penetration.

\subsubsection{Semi-rigid columns}

Lorenzo and Bergado (2003) derived an analytical solution to predict the consolidation rate of DM column-reinforced foundations based on a unit cell concept. In their model, it is assumed that the DM column has a higher permeability than the surrounding soil and all the water draining out from the surrounding soil enters the DM column and drains out vertically through the column. A 1D Terzaghi's solution was used to calculate the consolidation rate of the DM column. Lorenzo and Bergado (2003) did not model lateral drainage as Han and Ye (2001, 2002) did for the consolidation of stone column foundations. Miao et al. (2008) modelled the DM column-reinforced foundation as a composite foundation with a higher equivalent modulus than the untreated soil, and analysed the DM column-reinforced foundation over soft soil as a double-layer system. They assumed that the DM columns were impervious. Similar to Miao et al. (2008), Chai and Pongsivasathit (2009) treated the DM column foundation as a composite foundation with a higher equivalent modulus. However, Chai and Pongsivasathit (2009) proposed an equivalent permeability of the composite foundation, the same as the formula for vertical drains developed by Chai et al. (2001), as shown in Figure 15. The equivalent coefficient of volumetric compressibility and permeability of the composite foundation can be calculated as follows

16a. $m_{\mathrm{v} 1}=\frac{1}{a_{\mathrm{s}} D_{\mathrm{c}}+\left(1-a_{\mathrm{s}}\right) D_{\mathrm{s}}}$

$$
k_{\mathrm{v} 1}=\left(1+\frac{1 \cdot 5 H_{1}^{2}}{\mu d_{\mathrm{e}}^{2}} \frac{k_{\mathrm{r}}}{k_{\mathrm{v}}}\right) k_{\mathrm{v}}
$$




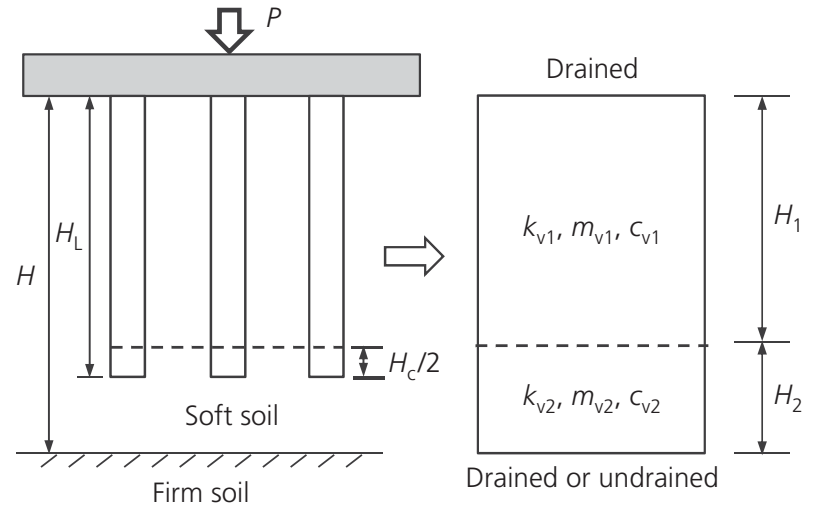

Figure 15. Consolidation of a column-reinforced soft foundation over soft soil (after Chai and Pongsivasathit (2009))

16c. $\mu=\ln \frac{N}{S}+\frac{k_{\mathrm{r}}}{k_{\mathrm{s}}} \ln (s)-\frac{3}{4}+\frac{8 H_{1}^{2} k_{\mathrm{r}}}{3 d_{\mathrm{c}}^{2} k_{\mathrm{c}}}$

where $m_{\mathrm{v} 1}$ is the coefficient of volumetric compressibility of the equivalent layer, $D_{\mathrm{c}}$ and $D_{\mathrm{s}}$ are the constrained moduli of the column and the soil, $H_{1}$ is the thickness of the equivalent layer, $d_{\mathrm{e}}$ is the diameter of the unit cell, $d_{\mathrm{c}}$ is the diameter of the column, $k_{\mathrm{r}}$ and $k_{\mathrm{v}}$ are the permeability of the soil in the radial and vertical directions, $k_{\mathrm{s}}$ is the permeability of the smear zone, $k_{\mathrm{c}}$ is the permeability of the column, $N$ is the diameter ratio of the unit cell to the column and $s$ is the diameter ratio of the smear zone to the column. With the equivalent parameters, the closed-form solution for the consolidation of two-layered soils by Zhu and Yin (1999) can be used to calculate the rate of consolidation.

Huang et al. (2009) found that the consolidation of the DM column foundation under the embankment could be accelerated by columns with higher stiffness than soft clay, even though the columns had the same permeability as soft clay. This finding was further confirmed by Jiang et al. (2013) in their numerical study. Figure 16 shows that the rate of consolidation increased with the modulus ratio of the elastic column to the soil when the column permeability was the same as the soil permeability.

Zhang et al. (2012) derived an elastic solution to consider the effect of the permeability of geosynthetic encasement on the consolidation rate of the encased stone column-reinforced foundation, and found the geosynthetic encasement had a limited effect on the consolidation rate because of the high permeability of geosynthetic products.

\subsection{Stability}

\subsubsection{Failure modes}

Figure 17 shows the possible failure modes of columns under embankments: $(a)$ sliding, (b) collapse (rotational), (c) bending, $(d)$ circular shear, $(e)$ horizontal shear and $(f)$ combined failure.

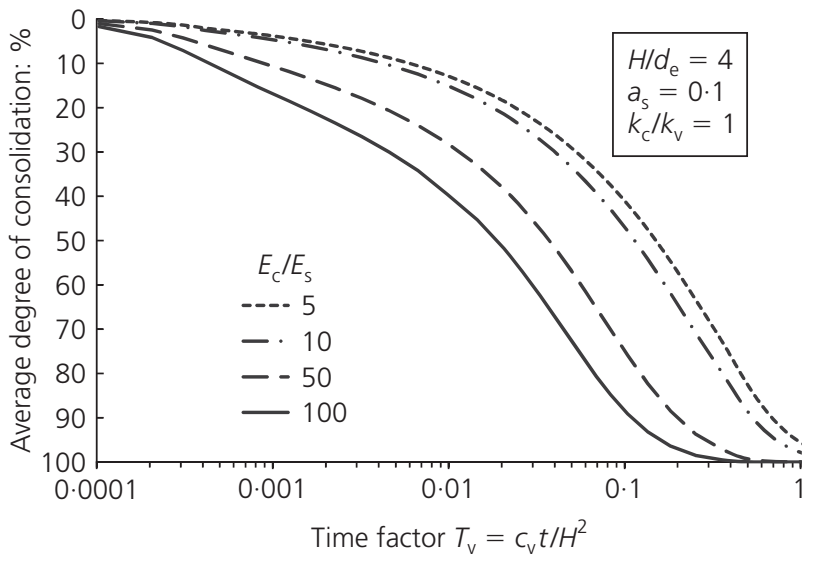

Figure 16. Effect of the modulus ratio on rate of the consolidation (after Jiang et al. (2013))

The actual failure mode of the column depends on its strength, rigidity, length and diameter, location and spacing, as well as on the end-bearing condition, the strength and stiffness of soft soil, and the height and slope angle of the embankment. Under certain conditions, there are combined failure modes, as shown in Figure 17(f).

\subsubsection{Flexible columns}

In practice, it is common to use equivalent parameters (cohesion, $c$, and friction angle, $\phi$ ) for flexible column-reinforced soft foundations in stability analysis. The equivalent parameters for the composite foundation are estimated based on the area average of these parameters from stone columns and the soft soil (e.g. Abusharar and Han, 2011; Cooper and Rose, 1999). Figure 18 shows the numerical models for individual columns and an equivalent area used in the Abusharar and Han (2011) study. The numerical analysis using the strength reduction method showed that the factor of safety of an embankment over an individual column-reinforced foundation was approximately $90 \%$ that of the embankment over a composite foundation with the equivalent parameters under an undrained condition (Abusharar and Han, 2011). The stress concentration effect on the columns is sometimes considered in the stability analysis (Kitazume, 2005).

\subsubsection{Rigid columns}

Zheng et al. (2010a) investigated numerically the stability of embankments over rigid column-reinforced foundations. They found that the bending moments and shear forces in the rigid columns increased with the increase of the embankment load. The bending failure occurred progressively on the rigid columns. In soft soil, after the bending failure of the column at a certain depth, the portion of the column above the failure location would rotate and still provide resistance to the stability of the embankment. In relatively firm soil, the second bending failure might occur in the upper portion of the column. 


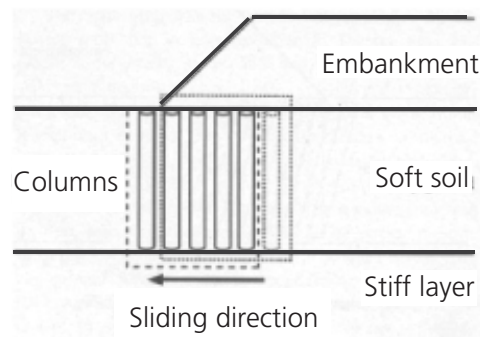

(a)

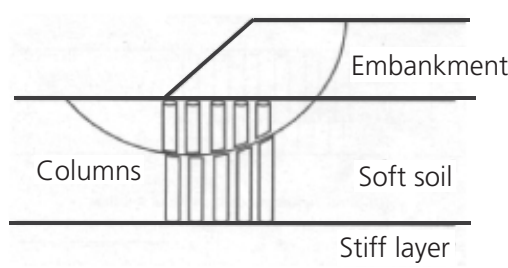

(d)

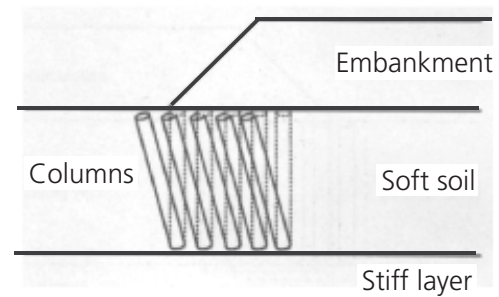

(b)

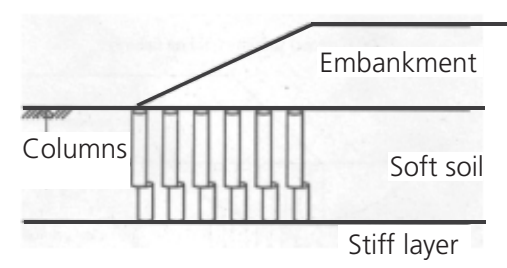

(e)

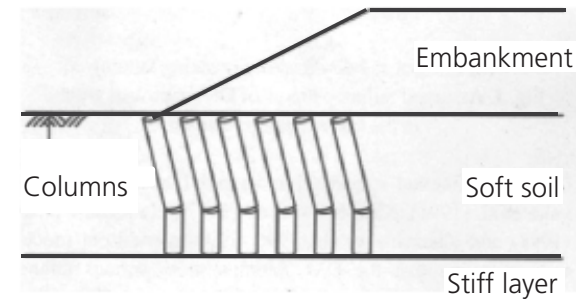

(c)

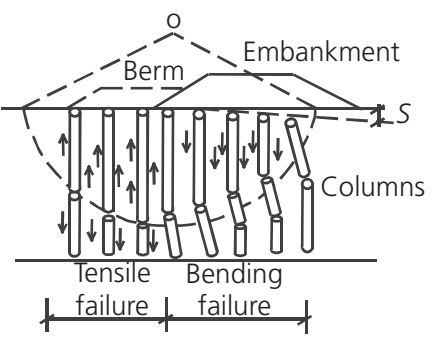

(f)

Figure 17. Possible failure modes of columns under embankments (modified from Broms (1999) and Kitazume (2008)): (a) sliding; (b) collapse (rotational); (c) bending; (d) circular shear; (e) horizontal shear; (f) combined

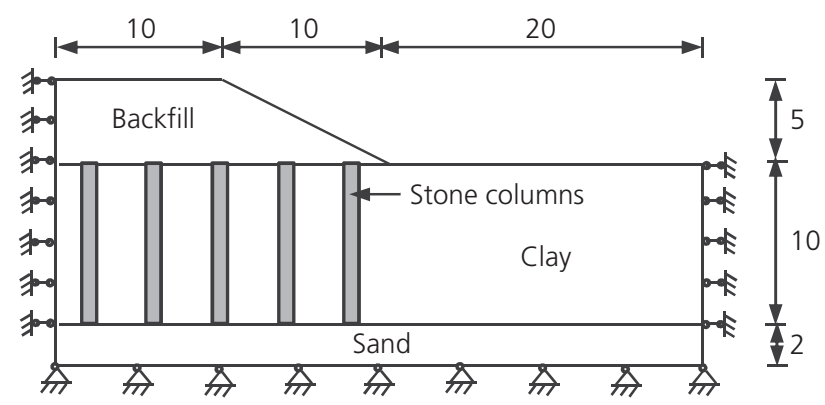

(a)

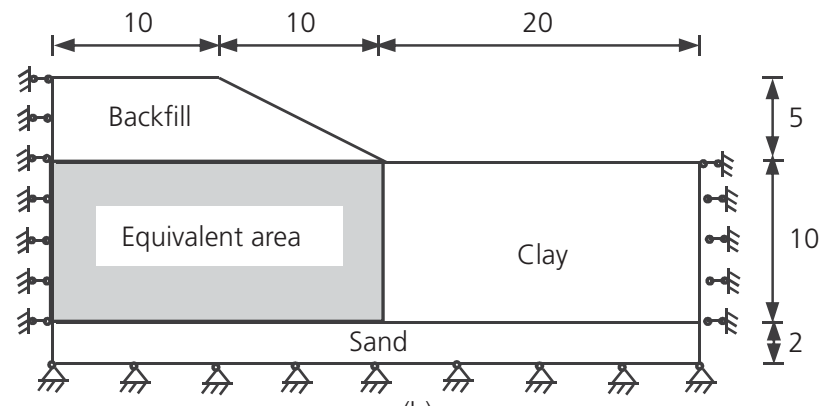

(b)

Figure 18. Equivalence of column-reinforced soft foundations for stability analysis (after Abusharar and Han (2011)): (a) individual columns; (b) equivalent area (unit: $\mathrm{m}$ )

\subsubsection{Semi-rigid columns}

Kitazume et al. (2000) investigated the failure modes of DM columns subjected to a vertical load or a combination of vertical and lateral loads in centrifuge tests. They found that the bearing capacities of DM column foundations under a combination of vertical and lateral loads were lower than those under vertical loads only. The DM columns under the combined loads ruptured at a lower column strength, but rotated at a higher column strength. Han et al. (2005), Filz and Navin (2006), and Han et al. (2010) found numerically that DM columns under embankments might fail due to shear, bending or rotation, depending on the strength of the columns. Rigid inclusions can be installed in granular or chemically stabilised soil columns to increase the shear and bending resistance of columns. Kitazume (2008) proposed two external failure modes (sliding and collapse) and three internal failure modes (circular shear, horizontal shear and bending), and developed simplified methods to estimate the embankment pressure at failure for collapse, horizontal shear and bending failures. It is challenging to develop a theoretical solution for the combined failure mode. A numerical method with a strength reduction approach may be used to estimate the factor of safety for this combined failure mode. Han et al. (2005) showed that the limit equilibrium method with a circular slip surface (e.g. Bishop's simplified method) overestimated the factor of safety of the embankment over a DM column-reinforced foundation determined by the numerical method using the strength reduction approach, as shown in Figure 19.

\section{Conclusions}

This paper presents a technical review of recent research and development in column technologies to improve soft foundations. The following key points can be summarised.

A variety of new column technologies have been developed and 


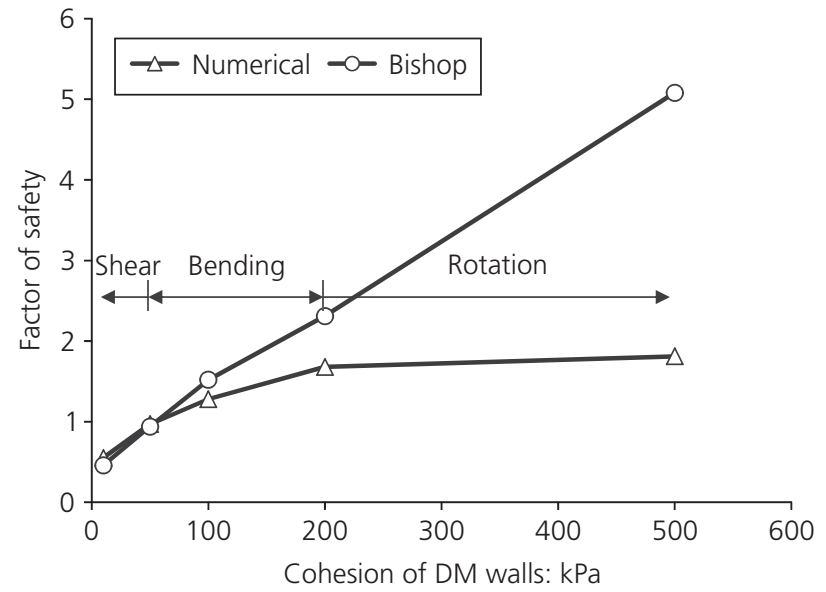

Figure 19. Limit equilibrium and numerical analyses of DM-wallsupported embankments (modified from Han et al. (2005))

successfully adopted for different applications. The columnsupported embankment is one of the most important applications in recent years. A large amount of research has been conducted to advance the knowledge of this embankment system. Among the column technologies, concrete columns have gained great acceptance in practice to improve soft foundations; however, more research is needed to develop the related design methods. Geosynthetic-encased stone columns have drawn great attention from researchers; however, field studies are needed to verify recent laboratory and theoretical developments.

Columns can be classified based on their installation method, column material and column rigidity. Based on column rigidity, columns can be classified into flexible, semi-rigid and rigid columns.

Research reveals that isolated columns can fail due to crushing, shear, punching and/or bulge under a compressive load; however, group columns under a combination of vertical and horizontal loads, such as embankment loading, can fail due to shear, bending, rotation or tension, or a combination of these. Limit equilibrium methods based on shear failure overestimate the factors of safety of embankments on rigid or semi-rigid columns in soft soil.

Columns have functions of load carrying, reinforcement, drainage and/or containment, and can be used to increase the bearing capacity, reduce settlement, accelerate consolidation and increase stability. Theoretical or approximate solutions are available to design individual columns or column-reinforced composite foundations considering these technical aspects. Significant advances have been made to develop or improve the theoretical solutions for the consolidation rate of column-reinforced soft foundations with different types of columns.

Lateral deformation and yielding of columns have effects on the stress transfer, settlement and rate of consolidation of the column-reinforced soft foundation; therefore, these should be considered in theoretical developments and practical design.

Research is needed to improve the approximation of using the theoretical solutions based on an equal-strain condition to evaluate the performance of column-supported embankments with differential settlements between columns.

Combined and composite column technologies have been increasingly used to combine their advantages and create effective and/ or economic solutions; however, they have also presented complicated geotechnical problems, posed challenges to design and construction, and provided opportunities for future research and applications.

\section{REFERENCES}

Aashto (American Association of State Highway and Transportation Officials) (2006) AASHTO LRFD Bridge Design Specifications. 2006 Interim Revisions. Aashto, Washington, DC, USA.

Aboshi H, Ichimoto E, Enoki M and Harada K (1979) The compozer - a method to improve characteristics of soft clays by inclusion of large diameter sand columns. Proceedings of the International Conference on Soil Reinforcement, ENPC,

Paris, France, vol. 1, pp. 211-216.

Abusharar S and Han J (2011) Two-dimensional deep-seated slope stability analysis of embankments over stone columns. Engineering Geology 120(1-4): 103-110.

Baez JI and Martin G (1995) Permeability and shear wave velocity of vibro-replacement stone columns. In Soil Improvement for Earthquake Hazard Mitigation (Hryciw RD (ed.)). American Society of Civil Engineers, Reston, VA, USA, GSP 49, pp. 66-81.

Barksdale RD and Bachus RC (1983) Design and Construction of Stone Columns. Federal Highway Administration, Washington, DC, USA, FHWA/RD-83/026.

Bhandari A and Han J (2009) Evaluation of high-capacity composite spun piles. Journal of Transportation Research Board 2116: 53-61.

Borel S (2007) Soil mixing innovations: Geomix, SpringSol and Trenchmix. Proceedings of Joint BGA/CFMS Meeting, London, UK.

Bouassida M, De Buhan P and Dormieux L (1995) Bearing capacity of a foundation resting on a soil reinforced by a group of columns. Géotechnique 45(1): 25-34, http:// dx.doi.org/10.1680/geot.1995.45.1.25.

Boulanger RW, Idriss IM, Stewart DP, Hashash Y and Schmidt B (1998) Drainage capacity of stone columns or gravel drains for mitigating liquefaction. Proceedings of Geotechnical Earthquake Engineering and Soil Dynamics III, ASCE, Seattle, WA, USA, pp. 678-690.

Brauns J (1978) Initial bearing capacity of stone column and sand piles. Proceedings of the Symposium on Soil Reinforcing and Stabilizing Techniques in Engineering Practice, Sydney, Australia, vol. I, pp. 497-512. 
Briançon L and Simon B (2012) Performance of pile-supported embankment over soft soil: full-scale experiment. Journal of Geotechnical and Geoenvironmental Engineering 138(4): 551-561.

Broms BB (1999) Can Lime/Cement Columns Be Used in Singapore and Southeast Asia? Nanyang Technological University and NTU-PWD Geotechnical Research Centre, Singapore, 3rd GRC Lecture.

Castro J and Sagaseta C (2009) Consolidation around stone columns - influence of column deformation. International Journal for Numerical and Analytical Methods in Geomechanics 33(7): 851-877.

Castro J and Sagaseta C (2011a) Deformation and consolidation around encased stone columns. Geotextiles and Geomembranes 29(3): 268-276.

Castro J and Sagaseta C (2011b) Consolidation and deformation around stone columns: numerical evaluation of analytical solutions. Computers and Geotechnics 38(3): 354-362.

Chai JC and Pongsivasathit S (2009) Prediction of consolidation settlements of floating column improved soft clayed subsoil. Proceedings of the International Symposium on Geotechnical Engineering, Ground Improvement and Geosynthetics for Sustainable Mitigation and Adaptation to Climate Change Including Global Warming, Bangkok, Thailand, pp. 107-115.

Chai JC, Shen SL, Miura N and Bergado DT (2001) Simple method of modeling PVD improved subsoil. Journal of Geotechnical and Geoenvironmental Engineering 127(11): 965-972.

Chai JC, Miura N, Kirekawa T and Hino T (2010) Settlement prediction for soft ground improved by columns. Proceedings of the Institution of Civil Engineers - Ground Improvement 163(2): 109-119, http://dx.doi.org/10.1680/ grim.2010.163.2.109.

Chen JF, Han J, Oztoprak S and Yang XM (2009) Behavior of single rammed aggregate pier. Computers and Geotechnics 36(7): 1191-1197.

Chen RP, Chen YM, Han J and Xu ZZ (2008) A theoretical solution for pile-supported embankments on soft soil. Canadian Geotechnical Journal 45(5): 611-623.

Chen RP, Xu ZZ, Chen YM, Ling DS and Zhu B (2010) Field tests of pile-supported embankments on soft ground. Journal of Geotechnical and Geoenvironmental Engineering 136(6): 777-785.

Chu J, Varaksin S, Klotz U and Menge P (2009) State of the Art Report - Construction Processes. Proceedings of the 17th International Conference on Soil Mechanics and Geotechnical Engineering, pp. 3006-3135.

Cooper MR and Rose AN (1999) Stone column support for an embankment on deep alluvial soils. Proceedings of the Institution of Civil Engineers - Geotechnical Engineering 37(1): 15-25, http://dx.doi.org/10.1680/geng.1999.137.1.015.

Debats JM, Guetif Z and Bouassida M (2003) Soft soil improvement due to vibrocompacted columns installation: Theory and practice. In Proceedings of the International Workshop on Geotechnics of Soft Soils, Noordwijkerhout, the
Netherlands (Vermeer PA, Schweiger HF, Karstunen M and Cudny M (eds)). VGE, Essen, Germany, pp. 551-556.

Douglas SC and Schaefer VR (2014) Reliability of the Priebe method for estimating settlements. Proceedings of the Institution of Civil Engineers - Ground Improvement 167(2): 108-121, http://dx.doi.org/10.1680/grim.12.00012.

Farrell T, Fitzpatrick B and Kenney W (2008) Uplift testing of rammed aggregate pier systems. Proceedings of Geotechnical Earthquake Engineering and Soil Dynamics IV, ASCE Geo Institute, Sacramento, CA, USA.

Filz GM and Navin MP (2006) Stability of Column-supported Embankments. Virginia Transportation Research Council, Charlottesville, VA, USA.

Filz G, Sloan J, McGuire MP, Collin J and Smith M (2012) Columnsupported embankments: settlement and load transfer. In Geotechnical Engineering State of the Art and Practice (Rollins K and Zekkos D (eds)). American Society of Civil Engineers, Reston, VA, USA, ASCE GSP No. 226, pp. 54-77.

Gniel J and Bouazza A (2009) Improvement of soft soils using geogrid encased stone columns. Geotextiles and Geomembranes 27(3): 167-175.

Guetif Z, Bouassida M and Debats JM (2007) Improved soft clay characteristics due to stone column installation. Computers and Geotechnics 34(2): 104-111.

Han J (2010) Consolidation settlement of stone columnreinforced foundations in soft soils. In New Technologies on Soft Soils, Proceedings of the Symposium on New Techniques for Design and Construction on Soft Clays, Brazil (Almeida M (ed.)). CRC Press, Boca Raton, FL, USA, pp. 167-179.

Han J and Gabr MA (2002) Numerical analysis of geosyntheticreinforced and pile-supported earth platforms over soft soil. Journal of Geotechnical and Geoenvironmental Engineering 128(1): 44-53.

Han J and Wayne MH (2000) Pile-soil-geosynthetic interactions in geosynthetic reinforced/piled embankments over soft soil. Proceedings of the 79th Annual TRB Meeting, Washington, $D C, U S A$, CD-ROM.

Han J and Ye SL (1991) Analysis of characteristics to composite grounds. Proceedings of the 1st Young Asian Geotechnical Engineers Conference, Bangkok, Thailand, pp. 197-206.

Han J and Ye SL (2001) Simplified method of consolidation rate of stone column reinforced foundation. Journal of Geotechnical and Geoenvironmental Engineering 127(7): 597-603.

Han J and Ye SL (2002) A theoretical solution for the rate of consolidation of a stone column reinforced foundation accounting for smear and well resistance. International Journal of Geomechanics 2(2): 135-151.

Han J, Zhou HT and Ye F (2002) State of practice review of deep soil mixing techniques in China. Journal of the Transportation Research Board 1808: 49-57.

Han J, Parsons RJ, Sheth AR and Huang J (2005) Factors of safety against deep-seated failure of embankments over deep mixed columns. Proceedings of the Deep Mixing 2005 Conference, Stockholm, Sweden, vol. 1.2, pp. 231-236. 
Han J, Yang XM, Chen JF and Porbaha A (2009) Settlement calculation of deep mixed foundations. Proceedings of the International Symposium on Deep Mixing and Admixture Stabilization, Okinawa, Japan, 19-21 May.

Han J, Chen JF, Hong ZS and Shen SL (2010) Mitigation of levee failure using deep mixed columns and geosynthetics. Geomechanics and Geoengineering: International Journal 5(1): 49-55.

Horikoshi K and Randolph MF (1999) Estimation of overall settlement of piled rafts. Soils and Foundations 39(2): 59-68.

Huang J, Han J and Oztoprak S (2009) Coupled mechanical and hydraulic modeling of geosynthetic-reinforced columnsupported embankments. Journal of Geotechnical and Geoenvironmental Engineering 135(8): 1011-1021.

Huang M and Li B (2009) Numerical analysis of pile-supported earth platforms with non-uniform piles. Advances in Ground Improvement (Han J, Zhang G, Schaefer VR and Huang M (eds)). American Society of Civil Engineers, Reston, VA, USA, GSP No. 188, pp. 46-54.

Hughes JMO and Withers NJ (1974) Reinforcing soft cohesive soil with stone columns. Ground Engineering 7(3): 42-49.

Jamsawang P, Bergado DT, Bhandari A and Voottipruex P (2008) Investigation and simulation of behavior of stiffened deep cement mixing (SDCM) piles. International Journal of Geotechnical Engineering 2(3): 229-246.

Jiang Y, Han J and Zheng G (2013) Numerical analysis of consolidation of soft soils fully-penetrated by deep-mixed columns. KSCE Journal of Civil Engineering 17(1): 96-105.

Khabbazian M, Kaliakin VN and Meehan CL (2010) Numerical study of the effect of geosynthetic encasement on the behavior of granular columns. Geosynthetics International 17(3): 132-143.

Kitazume M (2005) The Sand Compaction Pile Method. Balkema, Rotterdam, the Netherlands.

Kitazume M (2008) Stability of Group Column Type DM Improved Ground Under Embankment Loading. Port and Airport Research Institute, Yokosuka, Kanagawa, Japan, report 47(1).

Kitazume M, Okano K and Miyajima S (2000) Centrifuge model tests on failure envelope of column type mixing method improved ground. Soils and Foundations 40(4): 43-55.

Liu HL (2007a) New piling techniques for soil improvement in China. Proceedings of the 13th Asian Regional Conference on Soil Mechanics and Geotechnical Engineering, Kolkata, India.

Liu HL (2007b) Construction Method of X Shaped Pile. Chinese Patent \#2007100203063 (in Chinese).

Liu HL, Fei K, Ma XH and Gao YF (2003) Large-diameter driven cast-in-place concrete thin-wall pipe pile (I) research and development. Journal of Rock and Soil Mechanics 24: 164198 (in Chinese).

Liu SY, Han J, Zhang DW and Hong ZS (2008) A new DJM-PVD combined method for soft ground improvement. Geosynthetics International Journal 15(1): 43-54.

Liu SY, Du YJ, Li YL and Puppala AJ (2012) Field investigations on performance of T-shaped deep mixed (TDM) soil-cement columns supported embankment over soft ground. Journal of Geotechnical and Geoenvironmental Engineering 138(6): 718-727.

Lorenzo GA and Bergado DT (2003) New consolidation equation for soil-cement piles improved ground. Canadian Geotechnical Journal 40(2): 265-275.

McCabe B and Egan D (2010) A review of the settlement of stone columns in compressible soils. In Ground Improvement and Geosynthetics (Puppala AJ, Huang J, Han J and Hoyos LR (eds)). American Society of Civil Engineers, Reston, VA, USA, GSP No. 207, pp. 197-204,

McCabe B, Kamrat-Pietraszewska D and Egan D (2013) Ground heave induced by installing stone columns in clay soils. Proceedings of the Institution of Civil Engineers Geotechnical Engineering 166(6): 589-593, http://dx.doi.org/ 10.1680/geng.12.00103.

Miao L, Wang X and Kavazanjian E (2008) Consolidation of a double layered compressible foundation partially penetrated by deep mixed column. Journal of Geotechnical and Geoenvironmental Engineering 134(8): 1210-1204.

Moulton LK (1980) Highway Subdrainage Design. Offices of Research and Development, Federal Highway Administration, Washington, DC, USA, Report FHWA-TS-80-224.

Pongsivasathit S, Chai JC and Ding WQ (2013) Consolidation settlement of floating-column-improved soft clayey deposit. Proceedings of the Institution of Civil Engineers - Ground Improvement 166(1): 44-58, http://dx.doi.org/10.1680/ grim.11.00028.

Poulos HG (2001) Piled raft foundations - design and applications. Géotechnique 50(2): 95-113, http://dx.doi.org/ 10.1680/geot.2001.51.2.95.

Priebe HJ (1995) The design of vibro replacement. Ground Engineering 28(10): 31-37.

Pulko B and Majes B (2005) Simple and accurate prediction of settlements of stone column reinforced soil. Proceedings of the 16th International Conference on Soil Mechanics and Geotechnical Engineering, Osaka, Japan, pp. 1401-1404.

Raithel M and Kempfert HG (2000) Calculation models for dam foundations with geosynthetic coated sand columns.

Proceedings of the International Conference on Geotechnical and Geological Engineering, GeoEng 2000, Melbourne, Australia, pp. 347-352.

Raithel M, Kirchner A, Schade C and Leusink E (2005) Foundation of constructions on very soft soils with geotextile encased columns - state of the art. In Proceedings of GeoFrontiers - Innovations in Grouting and Soil Improvement (Schaefer VR, Bruce DA and Byle MJ (eds)). American Society of Civil Engineers, Reston, VA, USA, GSP No. 136, pp. 1867-1877.

Shen SL, Han J and Du YJ (2008) Deep mixing induced property changes in sensitive marine clays. Journal of Geotechnical and Geoenvironmental Engineering 134(6): 845-854.

Simon B and Schlosser F (2006) Soil reinforcement by vertical stiff inclusions in France. Proceedings of the Symposium on Rigid 
Inclusion in Difficult Subsoil Conditions, Mexico City, Mexico, pp. 1-22.

Springman SM, Kaue J, Gautray J and Askarinejad A (2014)

Ground improvement for embankments on soft ground. Proceedings of the Institution of Civil Engineers - Ground Improvement 167(3): 149-161, http://dx.doi.org/10.1680/ grim.13.00013.

Tan SA, Tjahyono S and Oo KK (2008) Simplified plane-strain modeling of stone-column reinforced ground. Journal of Geotechnical and Geoenvironmental Engineering 134(2): 185-194.

Van Eekelen SJM, Bezuijen A and Van Tol AF (2013) An analytical model for arching in piled embankments. Geotextiles and Geomembranes 39: 78-102.

Wang G (2009) Consolidation of soft clay foundations reinforced by stone columns under time-dependent loadings. Journal of Geotechnical and Geoenvironmental Engineering 135(12): 1922-1931.

Xie KH, Lu MM, Hu AF and Chen GH (2009a) A general theoretical solution for the consolidation of a composite foundation. Computers and Geotechnics 36(1-2): 24-30.

Xie KH, Lu MM and Liu GB (2009b) Equal strain consolidation for stone columns reinforced foundation. International Journal for Numerical and Analytical Methods in Geomechanics 33(15): 1721-1735.

Xu C, Ye GB, Jiang ZS and Zhou QZ (2006) Research on mechanism of combined improvement of soft soils based on field monitoring. Chinese Journal of Geotechnical Engineering 28(7): 918-921 (in Chinese).

Ye SL, Han J and Ye GB (1994) Soil Improvement and Underpinning, 2nd edn. The Chinese Building Industry Press, Beijing, China (in Chinese).

Zhang Y, Chan D and Wang Y (2012) Consolidation of composite foundation improved by geosynthetic-encased stone columns. Geotextiles and Geomembranes 32: 10-17.
Zheng G, Liu SY and Chen RP (2009a) State of advancement of column-type reinforcement element and its application in China. In Proceedings of the US-China Workshop on Ground Improvement Technologies, Advances in Ground Improvement, Orlando, Florida (Han J, Zheng G, Schaefer VR and Huang MS (eds)). American Society of Civil Engineers, Reston, VA, USA, Geotechnical Special Publication No. 188, pp. 12-25.

Zheng G, Liu L and Han J (2010a) Stability of embankment on soft subgrade reinforced by rigid piles (I) - background and single pile analysis. Chinese Journal of Geotechnical Engineering 32(11): 1648-1657 (in Chinese).

Zheng G, Liu L and Han J (2010b) Stability of embankment on soft subgrade reinforced by rigid inclusions (II) - group pile analysis. Chinese Journal of Geotechnical Engineering 32(12): 1811-1820 (in Chinese).

Zheng G, Jiang Y and Han J (2011) Performance of cement-fly ash-gravel pile-supported high-speed railway embankments over soft marine clay. Journal of Marine Georesources and Geotechnics 29(2): 145-161.

Zheng JJ, Liu Y and Xu ZJ (2009b) Reliability-based design applied to multi-column composite foundation. In Proceedings of the US-China Workshop on Ground Improvement Technologies, Advances in Ground Improvement, Orlando, Florida (Han J, Zheng G, Schaefer VR and Huang MS (eds)). American Society of Civil Engineers, Reston, VA, USA, Geotechnical Special Publication No. 188, pp. 83-91.

Zheng JJ, Zhang J and Ma Qiang Dong YK (2012) Experimental investigation of geogrid-reinforced and pile-supported embankment at bridge approach. Chinese Journal of Geotechnical Engineering 34(2): 355-362 (in Chinese).

Zhu G and Yin JH (1999) Consolidation of double soil layers under depth-dependent ramp load. Géotechnique 49(3): 415-421, http://dx.doi.org/10.1680/geot.1999.49.3.415.

\begin{abstract}
WHAT DO YOU THINK?
To discuss this paper, please email up to 500 words to the editor at journals@ice.org.uk. Your contribution will be forwarded to the author(s) for a reply and, if considered appropriate by the editorial panel, will be published as a discussion in a future issue of the journal.

Proceedings journals rely entirely on contributions sent in by civil engineering professionals, academics and students. Papers should be 2000-5000 words long (briefing papers should be 1000-2000 words long), with adequate illustrations and references. You can submit your paper online via www.icevirtuallibrary.com/content/journals, where you will also find detailed author guidelines.
\end{abstract}

